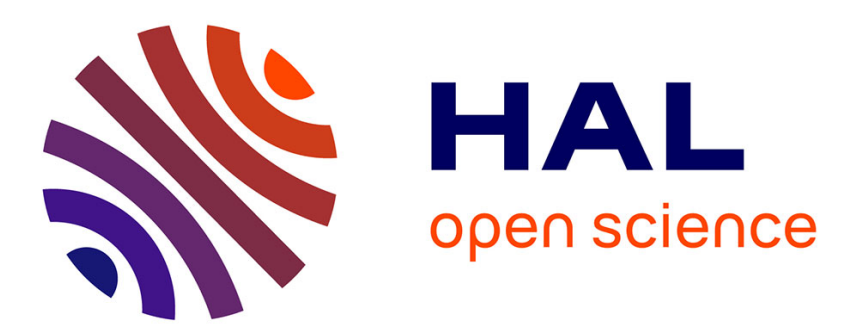

\title{
Extended validation of an expression to predict ORP and iron chemistry: Application to complex solutions generated during the acidic leaching or bioleaching of PCBs
}

\author{
Guikuan Yue, Anne-Gwenaëlle Guezennec, Edouard Asselin
}

\section{To cite this version:}

Guikuan Yue, Anne-Gwenaëlle Guezennec, Edouard Asselin. Extended validation of an expression to predict ORP and iron chemistry: Application to complex solutions generated during the acidic leaching or bioleaching of PCBs. Hydrometallurgy, 2016, 164, pp.334-342 10.1016/j.hydromet.2016.06.027 . hal-01427785

\section{HAL Id: hal-01427785 \\ https://hal-brgm.archives-ouvertes.fr/hal-01427785}

Submitted on 6 Jan 2017

HAL is a multi-disciplinary open access archive for the deposit and dissemination of scientific research documents, whether they are published or not. The documents may come from teaching and research institutions in France or abroad, or from public or private research centers.
L'archive ouverte pluridisciplinaire HAL, est destinée au dépôt et à la diffusion de documents scientifiques de niveau recherche, publiés ou non, émanant des établissements d'enseignement et de recherche français ou étrangers, des laboratoires publics ou privés. 


\section{Accepted Manuscript}

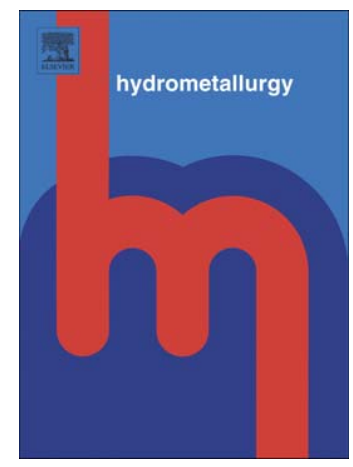

Extended validation of an expression to predict ORP and iron chemistry: Application to complex solutions generated during the acidic leaching or bioleaching of PCBs

Guikuan Yue, Anne-Gwénaëlle Guezennec, Edouard Asselin

PII:

S0304-386X(16)30398-X

DOI:

doi: 10.1016/j.hydromet.2016.06.027

Reference:

HYDROM 4393

To appear in: $\quad$ Hydrometallurgy

Received date: 5 January 2016

Revised date: $\quad 15$ June 2016

Accepted date: 25 June 2016

Please cite this article as: Yue, Guikuan, Guezennec, Anne-Gwénaëlle, Asselin, Edouard, Extended validation of an expression to predict ORP and iron chemistry: Application to complex solutions generated during the acidic leaching or bioleaching of PCBs, $\mathrm{Hy}$ drometallurgy (2016), doi: 10.1016/j.hydromet.2016.06.027

This is a PDF file of an unedited manuscript that has been accepted for publication. As a service to our customers we are providing this early version of the manuscript. The manuscript will undergo copyediting, typesetting, and review of the resulting proof before it is published in its final form. Please note that during the production process errors may be discovered which could affect the content, and all legal disclaimers that apply to the journal pertain. 


\title{
Extended validation of an expression to predict ORP and iron chemistry: application to complex solutions generated during the acidic leaching or bioleaching of PCBs
}

\author{
Guikuan Yue $^{\mathrm{a}, *}$, Anne-Gwénaëlle Guezennec ${ }^{\mathrm{b}}$, Edouard Asselin ${ }^{\mathrm{a}}$ \\ ${ }^{a}$ Department of Materials Engineering, The University of British Columbia, 309-6350 Stores Road, \\ Vancouver, BC, Canada V6T 1Z4 \\ ${ }^{\mathrm{b}}$ BRGM, Water, Environment \& Ecotechnologies Division, 3, av. Claude Guillemin, BP 36009, 45060 \\ Orléans Cedex 2, France
}

*Corresponding author, E-mail address: gkyue2008@gmail.com

The present work shows that the expression developed in our previous work to predict the redox potential of the quaternary $\mathrm{H}_{2} \mathrm{SO}_{4}-\mathrm{Fe}_{2}\left(\mathrm{SO}_{4}\right)_{3}-\mathrm{FeSO}_{4}-\mathrm{H}_{2} \mathrm{O}$ system can still be used to predict the redox potential of the $\mathrm{Fe}^{3+} / \mathrm{Fe}^{2+}$ couple in more complex acidic iron sulfate solutions generated during the acidic leaching and bioleaching of Printed Circuit Boards (PCBs). This expression can also be employed to determine the ferrous and ferric concentrations based on measured redox potential, temperature and total iron by AAS, especially in ferric or ferrous-dominant solutions. This equation therefore provides an alternative to the traditional colorimetric or volumetric methods for ferric and ferrous determination. The applicability of this equation in acidic iron sulfate solutions containing cupric ions was also supported by the experimental results in the literature. It is also shown that the measured redox potential is highly useful to estimate and understand the iron chemistry of industrial leaching processes.

Keywords: redox potential, iron chemistry, copper, oxidation, ferric 


\section{Introduction}

It is well-known that ferric ion is one of the most important and industrially relevant surrogate oxidants in many sulfide mineral leaching processes. It often already exists in hydrometallurgical leaching streams due to the dissolution of sulfide minerals such as chalcopyrite, pyrite, and bornite. Among various kinds of proposed leaching media, acidic iron sulfate solutions are common.

The iron sulfates present in sulfuric acid solution are distributed as soluble species including simple metal ions, neutral or charged complexes, as well as precipitates such as $\mathrm{Fe}_{2} \mathrm{O}_{3}$ formed at high temperatures (Dry and Bryson, 1988; Stipp, 1990; Casas et al., 2005; Cifuentes et al., 2006; Sapieszko et al., 1977; Filippou et al., 1995; Posnjak and Merwin, 1922; Sasaki et al., 1993; Umetsu et al., 1977; Papangelakis et al., 1994; Tozawa and Sasaki, 1986; Reid and Papangelakis, 2006; Liu et al., 2003). Therefore, a speciation model is required to quantify the distribution of $\mathrm{Fe}$ in acidic iron sulfate solutions and, further, to predict the redox potentials of the $\mathrm{Fe}^{3+} / \mathrm{Fe}^{2+}$ couple via the Nernst equation (Sapieszko et al., 1977; Dry and Bryson, 1988; Stipp, 1990; Yue et al., 2014a). These results, especially for the obtained redox potentials of the $\mathrm{Fe}^{3+} / \mathrm{Fe}^{2+}$ couple, can then be employed to study the kinetics of ferric ion reduction on semiconducting sulfide minerals, as well as to carry out mechanistic analyses and attendant optimization studies of industrial leaching processes (Jones, 1974; Li et al., 1992; Paramguru, 2002; Paramguru and Ray, 1996 and Yue et al. 2014a, 2014b, 2015). In addition, it should be emphasized that, in theory, according to the concept of mixed potential, the difference between the mixed potential measured on a sulfide mineral surface in a leaching environment and the cathodic redox potential of the $\mathrm{Fe}^{3+} / \mathrm{Fe}^{2+}$ couple, the cathodic over-potential, also represents the driving force for cathodic half-reaction (or clearly an indicator of the oxidizing power of the leaching solution) (Paramguru, 2002; Paramguru and Ray, 1996; Jones, 1974; Li et al., 1992; Power and Ritchie, 1981; Power et al., 1982; Zembura, 1968; Nicol, 1993).

The above discussion clearly demonstrates that the redox potential of acidic iron sulfate solutions is one of the key operating parameters in leaching systems. However, it is worth 
noting that this potential is determined by the activity ratio of free ferric to free ferrous (rather than the nominal concentration ratio). As a result, the speciation of the system is important in determining the redox potential (to obtain the relative amounts of free ferric and ferrous and the accompanying activity coefficients in the solution).

Although several relevant studies have examined the speciation of the quaternary acidic iron sulfate system $\left(\mathrm{H}_{2} \mathrm{SO}_{4}-\mathrm{Fe}_{2}\left(\mathrm{SO}_{4}\right)_{3}-\mathrm{FeSO}_{4}-\mathrm{H}_{2} \mathrm{O}\right)$ as a function of the initial amounts of iron, acidity, and temperature (Dry and Bryson, 1988; Stipp, 1990; Casas et al., 2005; Cifuentes et al., 2006; Sapieszko et al., 1977; Filippou et al., 1995), most of these are limited to lower concentrations and/or temperatures (below $90^{\circ} \mathrm{C}$ ). Hence, in our previous work, a thermodynamic model was developed and shown to reliably simulate the speciation of the $\mathrm{H}_{2} \mathrm{SO}_{4}-\mathrm{Fe}_{2}\left(\mathrm{SO}_{4}\right)_{3}-\mathrm{FeSO}_{4}-\mathrm{H}_{2} \mathrm{O}$ system through a wide range of solution compositions and temperatures $\left(25^{\circ} \mathrm{C}-150^{\circ} \mathrm{C}\right)$ where most of the hydrometallurgical processes of sulfide minerals operate (Yue et al., 2014a). Results from the calculated distribution of the main ferric and ferrous species in $\mathrm{H}_{2} \mathrm{SO}_{4}$ solutions reveal that most of the $\mathrm{Fe}(\mathrm{III})$ is distributed as complexes or precipitates and the free $\mathrm{Fe}^{3+}$ ions account for only a minor percentage, whereas a large amount of $\mathrm{Fe}(\mathrm{II})$ exists in the form of free $\mathrm{Fe}^{2+}$ ions. The Nernst equation was then used to study the redox potential of $\mathrm{Fe}^{3+} / \mathrm{Fe}^{2+}$ couple and it was shown that the speciation model explains the change of redox potential with temperature for all nominal ferric/ferrous ratios. Based on the speciation results, a novel expression (reproduced below) was also developed to predict the redox potential of the $\mathrm{Fe}^{3+} / \mathrm{Fe}^{2+}$ couple in the above-mentioned quaternary acidic iron sulfate electrolyte up to $150^{\circ} \mathrm{C}$. It seems that the redox potential can easily and accurately be determined only based on the variables of temperature and nominal ferric/ferrous ratio. Measured redox potentials by the present author and by others in the literature agree very well with those predicted by this expression, independent of the nominal concentrations of $\mathrm{Fe}^{3+}$ and $\mathrm{H}_{2} \mathrm{SO}_{4}$. Moreover, the proposed expression is probably applicable to more general cases at or around room temperature (or maybe slightly higher temperature), i.e., a wider range of solution composition. 


$$
E(\mathrm{mV})=-1 \times 10^{-3} \times[T(\mathrm{~K})]^{2}+0.91 \times T(\mathrm{~K})+\frac{2.303 R}{n F} \times T(\mathrm{~K}) \times 10^{3} \times \log \frac{C_{\text {ferric, nominal }}}{C_{\text {ferrous, nominal }}}+492
$$

There are still some interesting questions requiring further study regarding the broader range of applicability of this equation. For example, the co-existence of copper ions may affect the prediction of redox potential when leaching complex feeds such as copper-bearing sulfide minerals or metallic wastes (like PCBs, for recycling). It is also of interest to determine whether this equation remains applicable under bioleaching conditions, where bacteria catalyze the oxidation of ferrous iron into ferric iron.

The present work aims to provide new data on the extended validation of the expression developed previously, which can be used to predict the redox potential of the $\mathrm{Fe}^{3+} / \mathrm{Fe}^{2+}$ couple in the acidic iron sulfate system. An emphasis will also be placed on how to use this equation to understand the iron chemistry of the system under study, given measured redox potentials. The PCB leaching system was selected as the interest in the recycling of copper from this kind of metallic wastes has steadily increased, and the associated solution is fairly complicated. It was demonstrated that the previously proposed expression can still be used to predict the redox potential of the $\mathrm{Fe}^{3+} / \mathrm{Fe}^{2+}$ couple in these more complex acidic iron sulfate solutions. Based on the measured redox potential, the expression can also be used to understand the iron chemistry in these solutions, especially in a ferric-dominant or ferrous-dominant solution.

\section{Methodology}

\subsection{Materials and experimental}

Detailed information on the materials and experiments employed for the acidic leaching or bioleaching of PCBs can be found elsewhere (Guezennec et al., 2015). The present study has focused on the measurement of redox potential and its application to understanding the iron chemistry in acidic iron sulfate solutions. A detailed description of the experimental procedure and analytical method for iron determination is thus presented.

There are three types of leaching tests used in this work: (a) acidic leaching of PCBs at room temperature (b) bioleaching of PCBs at room temperature and (c) bioleaching of PCBs 
at about $40^{\circ} \mathrm{C}$ with air injection in order to enhance the bacterial activity. The first two types were carried out at ambient temperature and in triplicate. In these experiments, comminuted PCB samples $(<750 \mu \mathrm{m})$ were leached with an initial solid load of $2.5 \%$ in shaking flasks (containing $400 \mathrm{~mL}$ of a synthetic lixiviant solution without bacteria or $400 \mathrm{~mL}$ of the biogenic lixiviant solution and $10 \mathrm{~g}$ of PCBs). Two synthetic solutions, prepared by mixing deionized water with $\mathrm{Fe}_{2}\left(\mathrm{SO}_{4}\right)_{3} \bullet 7 \mathrm{H}_{2} \mathrm{O}$ salt, were tested. The initial concentration of $\mathrm{Fe}^{3+}$ and the initial $\mathrm{pH}$ in the synthetic solution depend from the amount of salts used for the preparation and were respectively $17.3 \mathrm{~g} / \mathrm{L}$ and 1.38 in the first one and $12.85 \mathrm{~g} / \mathrm{L}$ and $1.49 \mathrm{in}$ the second one. The biogenic solution was obtained from the bioleaching of mining waste mainly composed of pyrite. The bioleaching was performed with BRGM-KCC acidophilic and moderate thermophilic $\left(40^{\circ} \mathrm{C}\right)$ microbial consortium (Battaglia et al., 1994; d'Hugues et al., 2003). The predominant organisms in the culture are affiliated to the genera Leptospirillum, Acidithiobacillus and Sulfobacillus. These bacteria are autotrophic and known as iron-oxidizer. They are also known for their tolerance to high concentrations of various metals especially copper (Guezennec et al., 2014). The pulp obtained after bioleaching was first submitted to natural decantation (around $12 \mathrm{~h}$ ). The supernatant solution was then filtered at $0.65 \mu \mathrm{m}$ to remove particles while enabling bacteria to remain in the solution. The initial concentration of $\mathrm{Fe}^{3+}$ and the initial $\mathrm{pH}$ in the biogenic solution obtained were $18.32 \mathrm{~g} / \mathrm{L}$ and 1.19 .

For the third type of experiments, PCBs were leached with an air flow rate of $0.5 \mathrm{~L} / \mathrm{h}$ in a stirred tank reactor $(300 \mathrm{rpm}$, containing $1 \mathrm{~L}$ of the biogenic lixiviant solution and $26 \mathrm{~g}$ of PCBs) at $40^{\circ} \mathrm{C}$. The reactors were fully baffled; the agitation was performed using a dual impeller system consisting of a standard 6-blade flat-blade Rushton turbine for gas dispersion in combination with a 6-blade $45^{\circ}$ axial flow impeller to achieve solid suspension. These experiments were replicated once. The composition of the synthetic and biogenic lixiviant solutions used in the tests is described in Table 1. The $\mathrm{pH}$ in the biogenic solution is driven by the bio-oxidation of sulfides which produces larger amount of protons than the dissolution of 
the salt used for the preparation of the synthetic solution. This explains that the $\mathrm{pH}$ in the biogenic solution is slightly lower than that in the synthetic solution.

Each type of reactor was monitored regularly for temperature, $\mathrm{pH}$ (adjusted below 1.8 by adding $\mathrm{H}_{2} \mathrm{SO}_{4}(96 \%)$ ) and redox potential. Bacterial cells were counted regularly in biotic slurry samples. For each test, solution samples were taken and filtered at $0.45 \mu \mathrm{m}$ in order to monitor the concentrations of total $\mathrm{Fe}, \mathrm{Cu}, \mathrm{Ni}, \mathrm{Zn}$, and $\mathrm{Pb}$ (measured by $\mathrm{AAS}$ ) and of $\mathrm{Fe}^{2+}$ (determined by titration using cerium (IV) sulfate). The time interval between the sampling and the end of titration (for the chemical analysis) was typically between 30 and 45 min, with the time required to make the titration in the range of 10-15 min.

The redox potential of the solution was measured by a saturated $\mathrm{Ag} / \mathrm{AgCl}$ electrode. All measured potentials have been converted from $\mathrm{Ag} / \mathrm{AgCl}$ to the standard hydrogen electrode (SHE). All further potentials in this study are quoted with respect to the SHE at $25^{\circ} \mathrm{C}$ unless otherwise stated. Details of the corrections used for the measured potential are discussed below.

\subsection{Calculation of the solution redox potential via the equation developed previously}

Eq. (1), has only two variables: temperature and nominal ferric/ferrous ratio. Therefore, at any given temperature, the redox potential of the quaternary $\mathrm{H}_{2} \mathrm{SO}_{4}-\mathrm{Fe}_{2}\left(\mathrm{SO}_{4}\right)_{3}-\mathrm{FeSO}_{4}-\mathrm{H}_{2} \mathrm{O}$ system is solely determined by the nominal ferric/ferrous ratio. Consequently, in order to calculate the solution redox potential via the developed Eq. (1), apart from the measured temperature, the nominal ferric/ferrous ratio of the solution is also required. In the present study, the method used to calculate the nominal ferric/ferrous ratio was as follows: first, the total iron in the solution was measured by AAS; then, the nominal ferrous concentration was determined by cerium titration; and finally, calculation of the nominal ferric/ferrous ratio was carried out according to the following equation:

$$
\text { Nominal ferric/ferrous ratio }=\frac{[\text { Iron (total by AAS })]-[\text { ferrous (by cerium titration })]}{[\text { ferrous }(\text { by cerium titration })]}
$$




\subsection{Correction of the measured redox potentials to $\mathrm{SHE}$ at $25^{\circ} \mathrm{C}$}

The measured redox potentials of the solutions generated during the chemical or biochemical leaching of PCBs are compared with the calculated solution redox potentials by Eq. (1). Please note that all of the potentials $E(\mathrm{mV})$ calculated by this equation refer to SHE at $25^{\circ} \mathrm{C}$. Hence, the measured redox potentials should also be further corrected to SHE at $25^{\circ} \mathrm{C}$ by the method published previously (Yue et al., 2014a). The two equations involved in the correction procedure are as follows:

$$
\begin{aligned}
& E_{\mathrm{SHE}}(\mathrm{T})=E_{\mathrm{obs}}+E_{\text {correction }}=E_{\mathrm{obs}}+E_{\mathrm{Ag} / \mathrm{AgCl}}(\mathrm{T})-\Delta E_{\mathrm{th}} \\
& E_{\mathrm{SHE}}\left(25^{\circ} \mathrm{C}\right)=E_{\mathrm{SHE}}(\mathrm{T})+\Delta E_{\mathrm{SHE}}
\end{aligned}
$$

where $E_{\mathrm{SHE}}(\mathrm{T})$ is the potential of a Working Electrode (WE) in the reactor with $\mathrm{T}$ being the temperature of the solution versus the SHE at the operating temperature $\mathrm{T} ; E_{\mathrm{obs}}$ is the observed potential of a WE in the solution versus the $\mathrm{Ag} / \mathrm{AgCl}$ Reference Electrode (RE); $E_{\text {correction }}$ is a potential correction value; $E_{\mathrm{Ag} / \mathrm{AgCl}}(\mathrm{T})$ is the isothermal potential of the $\mathrm{Ag} / \mathrm{AgCl}$ electrode versus the SHE at the operating temperature $\mathrm{T} ; \Delta E_{\mathrm{th}}$ is the measured potential difference of the thermal cell between an internal and an external RE connected by a cooled salt bridge; $E_{\mathrm{SHE}}\left(25^{\circ} \mathrm{C}\right)$ is the potential with respect to a $\mathrm{SHE}$ at $25^{\circ} \mathrm{C} ; \Delta E_{\mathrm{SHE}}$ is the potential difference of the SHE thermal cell at $\mathrm{T}$ and $25^{\circ} \mathrm{C}$.

The experimental potentials from the BRGM $\left(E_{\mathrm{h}}\right)$ shown in the tables of Section 3 are the corrected values equal to the sum of $E_{\mathrm{obs}}$ and $E_{\mathrm{Ag} / \mathrm{AgCl}}(\mathrm{T})$ shown in Eq. (3). The method to determine $\Delta E_{\mathrm{th}}$ and $\Delta E_{\mathrm{SHE}}$ at different temperatures was shown in a previous publication (Yue et al., 2014a). Typically, the $\Delta E_{\text {th }}$ value varies from $-1.0 \mathrm{mV}$ to $0.5 \mathrm{mV}$ at around room temperature and is $\sim 5.8 \mathrm{mV}$ at about $40^{\circ} \mathrm{C}$; the $\Delta E_{\mathrm{SHE}}$ ranges from $-2.0 \mathrm{mV}$ to $0.7 \mathrm{mV}$ at around room temperature and is $\sim 9.8 \mathrm{mV}$ at about $40^{\circ} \mathrm{C}$.

\section{Results and discussion}

\subsection{Discussion on Eq. (1) at $25^{\circ} \mathrm{C}$ and $40^{\circ} \mathrm{C}$}

At $25^{\circ} \mathrm{C}$ and $40^{\circ} \mathrm{C}$, Eq. (1) can be converted to the following two equations, respectively: 


$$
\begin{aligned}
& E_{298.15 \mathrm{~K}}(\mathrm{mV})=674.42+59.167 \times \log \frac{C_{\text {ferric, nominal }}}{C_{\text {ferrous, nominal }}} \\
& E_{313.15 \mathrm{~K}}(\mathrm{mV})=678.90+62.144 \times \log \frac{C_{\text {ferric, nominal }}}{C_{\text {ferrous, nominal }}}
\end{aligned}
$$

From Eq. (5) and (6), it can be seen that the redox potential of the quaternary $\mathrm{H}_{2} \mathrm{SO}_{4}-\mathrm{Fe}_{2}\left(\mathrm{SO}_{4}\right)_{3}-\mathrm{FeSO}_{4}-\mathrm{H}_{2} \mathrm{O}$ system is solely determined by the nominal ferric/ferrous ratio at constant temperature.

Table 2 shows the calculated redox potentials according to Eqs. (5) and (6) in the $\mathrm{Fe}(\mathrm{II})-\mathrm{Fe}(\mathrm{III})-\mathrm{H}_{2} \mathrm{SO}_{4}$ solutions at $25^{\circ} \mathrm{C}$ and $40^{\circ} \mathrm{C}$ with different nominal ferric/ferrous ratios. $\Delta E$ is the potential difference for the calculated potentials between a nominal ferric/ferrous ratio with an assumed error and a given nominal ferric/ferrous ratio. The assumed errors for nominal ferric/ferrous ratios are $2 \%, 5 \%, 10 \%, 15 \%$ and $20 \%$, respectively. Take $\Delta E_{1}$ as an example: the $\Delta E_{1}$ is $0.51 \mathrm{mV}$ when there is an assumed error of $+2 \%$ for a given nominal ferric/ferrous ratio (given nominal ferric/ferrous ratio $\times 1.02$ ); while this value is $-0.52 \mathrm{mV}$ when there is an assumed error of $-2 \%$ for a given nominal ferric/ferrous ratio (given nominal ferric/ferrous ratio $\times 0.98$ )

Based on the results in Table 2, it can be seen that even if there is an error of a real nominal ferric/ferrous ratio up to $\pm 15 \%$, the deviation of the calculated redox potential according to Eq. (1) does not exceed $\sim 4 \mathrm{mV}$. This implies that the accuracy of the predicted redox potential by Eq. (1) is acceptable as long as the employed nominal ferric/ferrous ratio is accurate or at least the error is no more than $20-30 \%$, for example. The error of the calculated nominal ferric/ferrous ratio can result from the total iron or ferrous ion concentration measurement, or both.

However, when using the measured redox potential to predict the nominal ferric/ferrous ratio based on Eq. (1) (or Eq. (5) and Eq. (6)), in order to understand the iron chemistry in the leaching solution, it would be preferable that the error for the measured redox potential is within 3-4 $\mathrm{mV}$. Otherwise, there is a relatively large error existing for the calculated nominal ferric/ferrous ratio based on the measured redox potential. This is due to the fact that the 
nominal ferric/ferrous ratio is much more sensitive and a smaller error in the measured redox potential can lead to a large deviation for the predicted nominal ferric/ferrous ratio. As a result, when using Eq. (1) to understand the iron chemistry in the leaching solution, caution should be taken for the experimental measurement of the redox potential. For example, the Pt working electrode needs to be well cleaned, the reference electrode should be calibrated by standard solution, and the systematic error should be eliminated.

\subsection{Acidic leaching of PCBs at room temperature}

PCBs were leached in $\mathrm{Fe}^{3+}$ and $\mathrm{H}_{2} \mathrm{SO}_{4}$ solution at room temperature. What particularly interests us is whether the co-existence of copper can exert an influence on the prediction of redox potentials by Eq. (1). Table 3 and Table 4 present the results for the solution generated by acidic leaching of PCBs samples $(<750 \mu \mathrm{m})$ at room temperature with an initial solid load of $2.5 \%$ in shaking flask (containing $400 \mathrm{~mL}$ of a synthetic lixiviant solution including $\mathrm{Fe}^{3+}$ and $\mathrm{H}_{2} \mathrm{SO}_{4}$ without bacteria). The initial concentrations of $\mathrm{Fe}^{3+}$ were about $18 \mathrm{~g} / \mathrm{L}$ and $13 \mathrm{~g} / \mathrm{L}$, respectively.

\subsubsection{Comparison of redox potential between calculated results and experimental measurements with the initial $\mathrm{Fe}^{3+}$ concentrations of $18 \mathrm{~g} / \mathrm{L}$}

As discussed in a previous publication (Guezennec et al., 2015), the choice of this particular initial $\mathrm{Fe}^{3+}$ concentrations $(\sim 18 \mathrm{~g} / \mathrm{L})$ is due to the fact that this value corresponded to a stoichiometric ratio of 2 for the following reaction and hence the $\mathrm{Fe}^{3+}$ amount was considered adequate for leaching based on the concentration of $\mathrm{Cu}, \mathrm{Ni}, \mathrm{Zn}, \mathrm{Pb}, \mathrm{Fe}$ and $\mathrm{Sn}$ in the PCBs.

$$
\mathrm{M}^{0}+2 \mathrm{Fe}^{3+}=\mathrm{M}^{2+}+2 \mathrm{Fe}^{2+}
$$

It is shown in Table 3 that the $\mathrm{Fe}^{3+}$ concentration in the leaching solution decreases quickly at the very beginning of the leaching experiments because of the high dissolution rate of metallic elements in the PCBs according to Eq. (7). At the same time, there is a sharp increase in the $\mathrm{Fe}^{2+}$ concentration $(\sim 9.5 \mathrm{~g} / \mathrm{L})$ and its value finally approaches $\sim 16 \mathrm{~g} / \mathrm{L}$. A combination of the above-mentioned two factors leads to the fact that, apart from the starting point, in 
general, the calculated values of nominal ferric/ferrous ratio according to Eq. (2) are in the range of 0.09-0.97 (implying that the ferric concentration in the leach solution is always less than that of ferrous). Despite the fact the ferrous concentration in the leaching solution continuously increases, there is a minor fluctuation for the total iron amount. This may be due to possible reactions that consume $\mathrm{Fe}^{3+}$, such as the formation of jarosite precipitates (Guezennec et al., 2015). There is also a possibility that such a phenomenon is caused by the minor error from the determination of the average Fe content in PCBs, or the error from the determination of total iron by AAS (typically no more than 3-5\%), or by a combination of both of these factors. The total iron amount in the leaching solution eventually increases and this is probably caused by the dissolution of metallic iron in the PCBs.

Obviously, from Table 3, it can be seen that the measured redox potentials (after correction to SHE at $25^{\circ} \mathrm{C}$ ) and those calculated by Eq. (1) agree very well. This is, despite the co-existence of $\mathrm{Cu}, \mathrm{Ni}, \mathrm{Pb}$, and $\mathrm{Zn}$ ions in solution. The difference, $(\Delta E)$, between experimental and calculated values was calculated according to following equation:

$$
\Delta E=E(\text { Meas })-E(\text { Calc })
$$

It is interesting to note that the values of $\Delta E$ are negative in most cases, which means that the measured potentials are lower than the calculated ones (typically within an error of 13 $\mathrm{mV}$ ). Considering the fact that AAS for the determination of total iron concentration is generally reliable, this phenomenon may be caused by a small error in the amount of ferrous calculated by the cerium titration. This lower ferrous amount would result in a larger nominal ferric/ferrous ratio as determined by Eq. (2), which eventually leads to a larger calculated redox potential by Eq. (1). According to the literature (Peters, 1986), the homogeneous reaction (9), shown as follows, can consume a very small amount of ferrous in the solution sample and at the same time its kinetics can also be catalyzed by copper ions in the solution (probable reason).

$$
4 \mathrm{Fe}^{2+}+\mathrm{O}_{2}+4 \mathrm{H}^{+}=4 \mathrm{Fe}^{3+}+2 \mathrm{H}_{2} \mathrm{O}
$$


During the leaching test, metallic copper in the PCBs was continuously dissolved and hence copper ions co-exist in the leaching solution with its concentration in the range of $\sim 2-5$ $\mathrm{g} / \mathrm{L}$ (dominant ions apart from iron ions, as shown in Table 3). Therefore, the relatively lower ferrous amount determined by cerium titration may be attributed to its probable consumption by reaction 9 and/or the catalysis effect of copper ions on Reaction 9 (the oxidation reaction of ferrous ion to ferric ion).

The applicability of Eq. (1) in acidic iron sulfate solutions containing cupric ions was also investigated based on the experimental results in the literature in terms of nominal amounts of $\mathrm{Fe}^{3+}, \mathrm{Fe}^{2+}, \mathrm{Cu}^{2+}$ and $\mathrm{H}_{2} \mathrm{SO}_{4}$, as well as nominal ferric/ferrous ratio. Fig. 1 shows a comparison of the redox potentials in the $\mathrm{Fe}(\mathrm{II})-\mathrm{Fe}(\mathrm{III})-\mathrm{H}_{2} \mathrm{SO}_{4}$ solutions containing cupric ions predicted by Eq. (1) and measured by experiments from Hiroyoshi et al. (2000 and 2008) in $0.1 \mathrm{~mol} / \mathrm{L}$ $\mathrm{H}_{2} \mathrm{SO}_{4}$ at various nominal concentrations of $\mathrm{Fe}(\mathrm{III}) / \mathrm{Fe}(\mathrm{II})$ containing $\mathrm{Cu}^{2+}$ with different nominal ferric/ferrous ratios at room temperature. In Fig. 1, it is demonstrated that for each nominal ferric/ferrous ratio, the measured redox potentials can be solely determined by nominal ferric/ferrous ratio. The measured redox potentials are in good agreement with the results calculated by Eq. (1), with a deviation typically lower than $4.5 \mathrm{mV}$. It should be noted that wide ranges of nominal $\mathrm{Fe}^{3+}$ concentration $(0.002-0.5 \mathrm{~mol} / \mathrm{L})$, nominal $\mathrm{Fe}^{2+}$ concentration (0.001-0.5 mol/L), nominal $\mathrm{Cu}^{2+}$ concentration $(0.001-0.1 \mathrm{~mol} / \mathrm{L})$ and nominal ferric/ferrous ratios (from 0.002:1 to 200:1) are employed. The above analyses of the experimental results from the literature further strongly support the previous proposed Eq. (1) in acidic iron sulfate solutions containing cupric ions.

Finally, in Table 3, it is interesting to observe that in all three leaching tests, no "nominal" ferrous concentrations are reported at the beginning of the experiments. This means than all of the iron should exist in the form of ferric. However, from a thermodynamic point of view, there should always be a trace amount of ferrous in solution. The ensuing ferric/ferrous couple is necessary to support the measured redox potential with a value of $913.6 \mathrm{mV}$ (after correction to SHE at $25^{\circ} \mathrm{C}$ ). Technically, it is difficult to determine such a small amount of ferrous in solution (for example, a large error exists when carrying out the titration), or it is 
also very complicated or expensive to do such an analysis by other methods. However, based on the measured temperature and redox potential, and through Eq. (1), a nominal ferric/ferrous ratio can be calculated. Then, using the known total iron concentration determined by AAS, the nominal ferric and ferrous amounts in the initial solution can be obtained. This calculation results in an initial nominal ferrous concentration of $1.47 \mathrm{mg} / \mathrm{L}$ (a corresponding calculated nominal ferric/ferrous ratio of 11735.77).

The above analysis of the leach starting points indicates that Eq. (1) can be highly useful for understanding iron chemistry when the ferrous amount is extremely low, by calculating nominal ferric/ferrous ratios from measured redox potentials. At the very least, it provides an alternative to the traditional titration method to determine the ferrous concentration in solution, especially for a ferric-dominant solution.

\subsubsection{Comparison of redox potential between calculated results and experimental} measurements with the initial $\mathrm{Fe}^{3+}$ concentrations of $13 \mathrm{~g} / \mathrm{L}$

From the discussion in the previous Section, it seems that the co-existence of copper ions has no obvious influence on the prediction of redox potentials by Eq. (1). Hence, this equation can be used to understand the iron chemistry in real leaching solutions. In this section, the experiments had lower initial $\mathrm{Fe}^{3+}$ concentrations of $13 \mathrm{~g} / \mathrm{L}$, which was lower than the stoichiometric amount required to dissolve the metallic elements in the PCBs according to Eq. (7). Thus most of the iron in the final leach solution should exist in the form of ferrous, which is clearly shown in Table 4.

Particularly, the obtained ferrous amounts were even larger than those corresponding total iron amounts determined by AAS for the chemical analysis of Assays 7-10 in Test 1 and Assays 9-10 in Test 3. For such cases, the calculated values of nominal ferric/ferrous ratio are negative and hence Eq. (1) cannot be used to predict the redox potentials. In addition, from the chemical analysis of Assays 9-10 in Test 2, it can be seen that although the ferrous amount by titration did not exceed the total iron amount by AAS, there is a poor agreement between the measured redox potentials and the calculated values by Eq. (1). Further, the calculated values are always lower than those that are measured. These results indicate that there is 
probably an error for the ferrous amount determined by titration, or the total iron determined by AAS. Considering the fact that AAS for the determination of total iron is generally considered to be reliable, this phenomenon may result from a small error in the amount of ferrous calculated by the cerium titration.

The above analyses imply that the ferrous amount determined by titration is probably higher than the real ferrous amount in the solution. Therefore, it seems that in a ferrous-dominant acidic iron sulfate solution, the cerium titration method to determine the ferrous amount will probably not reflect the real solution composition, especially with nominal ferric/ferrous ratios smaller than 0.01 .

As shown previously, based on the measured redox potentials and temperature from Eq. (1), as well as the total iron determined by AAS, the ferrous amount can be calculated. As an example, for the chemical analysis of Assay 7 in Test 1 , a decrease in the ferrous amount to $12.86 \mathrm{~g} / \mathrm{L}$ will result in a calculated redox potential by Eq. (1) equal to that obtained by measurement, with a corresponding obtained nominal ferric/ferrous ratio of 0.042 . Hence, it seems that an error of $c a .5 \%$ exists when determining the ferrous amount by cerium titration. Similarly, by further calculating values for the remaining 7 assays, it was found that typically the positive error for ferrous titration was approximately in the range of 1.7-5.9\%. However, it should be emphasized that such a small value of the ferrous titration error leads to the fact that Eq. (1) cannot be applied.

Therefore, from the above discussion, it appears that Eq. (1) can also be used to understand the iron chemistry in a ferrous-dominant solution. And it is much more convenient and easier to determine the ferrous amount only based on the measured redox potentials, temperatures and total iron by AAS. In this way, the accuracy of the ferrous amount determined by cerium titration can also be checked to see whether the obtained result is reasonable or not.

\subsection{Bioleaching of PCBs at room temperature}

The results of the solution generated by bioleaching of PCBs samples $(<750 \mu \mathrm{m})$ at room temperature with an initial solid load of $2.5 \%$ in shaking flasks (containing $400 \mathrm{~mL}$ of the 
biogenic lixiviant solution produced from the bioleaching of mining wastes) are presented in Table 5. The initial concentrations of $\mathrm{Fe}^{3+}$ were about $18 \mathrm{~g} / \mathrm{L}$.

It is clearly shown that the agreement between the measured redox potential and those calculated by Eq. (1) (using the available chemical analyses) is poor in most cases, compared with the data presented in Tables 3 and 4 . Although the initial concentration of $\mathrm{Fe}^{3+}$ was about $18 \mathrm{~g} / \mathrm{L}$ and although relatively high $\mathrm{Fe}^{3+}$ concentrations were maintained during the experiments, it was found that a relatively large error exists between measured and predicted potentials, typically 10 to $24 \mathrm{mV}$. For the initial measurement, a ferrous concentration of $0.042 \mathrm{~g} / \mathrm{L}$ was reported by cerium titration and the agreement between the two redox potentials (calculated and measured) is good. In addition, for Assay 2 in Test 1, a value of $\sim 4.10 \mathrm{~g} / \mathrm{L}$ ferrous would be required for measured and predicted values to agree (compared to a reported value of $7.54 \mathrm{~g} / \mathrm{L}$ by titration).

In addition, it should be mentioned that it was even worse when the initial concentration of $\mathrm{Fe}^{3+}$ was about $11 \mathrm{~g} / \mathrm{L}$ (not shown as the agreement is poor for most data points), compared to those with the initial $\mathrm{Fe}^{3+}$ concentration of $18 \mathrm{~g} / \mathrm{L}$. This is because a smaller value of initial $\mathrm{Fe}^{3+}$ concentration leads to the fact that there was always a larger amount of ferrous in the leach solution and consequently the calculated nominal ferric/ferrous ratio was low. In most cases the ferrous amounts are larger than the total iron determined by AAS. This is likely due to the high metal content in the PCBs and a value of $11 \mathrm{~g} / \mathrm{L}$ is just under the amount of oxidant required to oxidize and dissolve all the base metals.

Further detailed studies would be required to investigate whether the reason for the over-estimation of ferrous concentration in the leaching solution by cerium titration can be linked to the bacteria's behavior or not. However, it is clearly shown that the ferrous amount determined by cerium titration under these conditions is inaccurate in most cases.

Currently, we believe that this is mainly due to experimental error in the analytical procedure to determine ferrous at higher concentrations and with a lower nominal ferric/ferrous ratio. The error from the calculated nominal ferric/ferrous ratios finally leads to the error between the measured redox potential and calculated potential from Eq. (1). 


\subsection{Bioleaching of PCBs at about $40^{\circ} \mathrm{C}$ with air injection}

Table 6 shows the results for the solution generated by bioleaching of PCBs samples $(<750$ $\mu \mathrm{m})$ at about $40^{\circ} \mathrm{C}$ with an initial solid load of $2.5 \%$ in a stirred tank reactor (300 rpm, containing $1 \mathrm{~L}$ of the biogenic lixiviant solution). The air flow rate was $0.5 \mathrm{~L} / \mathrm{h}$ and the initial concentration of $\mathrm{Fe}^{3+}$ was $\sim 18 \mathrm{~g} / \mathrm{L}$. The enhancement of temperature and the air injection (to provide oxygen) were employed in order to increase the bacterial activity and hence to favor the biological oxidation of ferrous ion generated by the oxidative leaching of PCBs. As a result, a higher amount of ferric ion can be maintained during the course of leaching.

As expected, from Table 6, it is obvious that apart from the starting point, in general the nominal ferric/ferrous ratios are in the range of 1.06-1.70. A higher level of ferric in solution was kept, due to the catalysis effect of bacteria on the re-oxidation of ferrous ions according to Eq. (9). Although the nominal ferric/ferrous ratio decreases quickly to a value of 1.1 at the very beginning, it gradually increased to reach a value of 1.6-1.7 at the end of the leaching experiments.

The redox potentials measured by experiment and calculated by Eq. (1) under different nominal ferric/ferrous ratios are in excellent agreement with each other. The difference between experimental and calculated values was negative and typically smaller than $17.9 \mathrm{mV}$ depending on the solution composition. This trend is similar to the result in Table 3 and indicates that the ferrous amount determined by titration is lower than the real ferrous amount in the solution. At the initial stages of the leach (Assay 1 for tests 1 and 2), a larger error was found, which is probably caused by the fact that most of the iron exists in the form of ferric. A decrease in the ferrous concentration to $0.038 \mathrm{~g} / \mathrm{L}$ (compared to a reported value of $0.15 \mathrm{~g} / \mathrm{L}$ by titration) would result in calculated and measured redox potentials being equal, with a corresponding obtained nominal ferric/ferrous ratio of 483.81 .

There is a concern about the influence on the measured ORP resulting from oxygen introduced into the solution. However, according to the literature, there is considerable evidence that, for the oxidation of sulfide minerals such as $\mathrm{PbS}, \mathrm{ZnS}, \mathrm{CuS}$ and $\mathrm{Cu}_{2} \mathrm{~S}$ in acid solutions and possibly for $\mathrm{CuFeS}_{2}$ as well, the dissolved ferric/ferrous couple plays an 
important catalytic role in accelerating the leaching rate with oxygen as an oxidant (Peters, 1986; Schlesinger et al., 2011). Although oxygen exists in most leaching processes, it is generally believed that oxygen plays a central role in the regeneration of ferric by re-oxidizing the ferrous ion, and the ferric/ferrous redox couple acts in a catalytic manner in these reactions (Peters, 1986; Schlesinger et al., 2011). This is because the kinetics of reduction of oxygen are sufficiently slow and the ferric reduction is always dominant. Hence, it seems that there is little or no influence on measured ORP resulting from the oxygen. The fact that the redox potentials measured by experiment and predicted by Eq. (1) are in good agreement appears to justify this assumption.

\subsection{Discussion on the findings in this work and its possible applications}

The above discussion clearly shows that in general, Eq. (1) can still be used to predict the redox potential of the ferric/ferrous couple in even more complicated acidic iron sulfate systems (even with a relatively large error for the nominal ferric/ferrous ratio determined by experiment). It may also be used to understand iron chemistry based on the measured redox potential in the complicated solutions generated during the acidic leaching or bioleaching of PCBs. As shown previously, in such a case, the deviation of measured redox potential should be no more than 3-4 mV. Provided that the accuracy of the redox potential measurement and total iron determination by AAS is ensured, Eq. (1) provides an alternative to the determination of ferric and ferrous amount in the leaching solutions, especially for a ferric-dominant solution or a ferrous-dominant solution.

It seems that under conditions when either a large amount of ferric or a large amount of ferrous exists in the acidic iron sulfate solution, there is an error when determining the ferrous amount by cerium titration. Even a small error can result in a very poor agreement between the measured redox potential and those predicted by Eq. (1). This means that for those cases the ferrous amount determined by titration is not accurate: it is either under-estimated or over-estimated. Please note that under those conditions the calculated nominal $\mathrm{Fe}^{3+} / \mathrm{Fe}^{2+}$ ratios are either too high or too low. 
For example, as shown in Section 3.2.2, an error of up to $6 \%$ of the ferrous concentration in the solution leads to the fact that Eq. (1) cannot be used in a ferrous-dominant solution. However, when increasing the nominal ferric/ferrous ratios to over 1 as shown in Section 3.4, even when solutions are complex, Eq. (1) can still be applied. As an example, for the chemical analysis of Assay 2 in Test 1 of Table 6, a decrease in the ferrous amount to 9.29 $\mathrm{g} / \mathrm{L}(6 \%$ percent lower) or an increase in the ferrous amount to $10.49 \mathrm{~g} / \mathrm{L}$ (6\% percent higher) will result in the calculated redox potentials remaining accurate to within $3 \mathrm{mV}$. Hence, there seems to be a range of nominal ferric/ferrous ratios where cerium titration for ferrous is accurate. From the present study, this range seems to be from 0.01 to 100 , however, more detailed studies are required to support this.

For a pure quaternary $\mathrm{H}_{2} \mathrm{SO}_{4}-\mathrm{Fe}_{2}\left(\mathrm{SO}_{4}\right)_{3}-\mathrm{FeSO}_{4}-\mathrm{H}_{2} \mathrm{O}$ system, based on previous study, Eq. (1) can be used in a pH range of $0.55-1.5$ (Yue et al. 2014a and the cited literature in Section 4.5 in this paper). Please note in Dry and Bryson, 1988, the solution with the highest nominal $\mathrm{H}_{2} \mathrm{SO}_{4}$ concentration can be about $1.02 \mathrm{~mol} / \mathrm{L}$, corresponding to an even much lower $\mathrm{pH}$ value. For solutions with $\mathrm{H}_{2} \mathrm{SO}_{4}-\mathrm{Fe}_{2}\left(\mathrm{SO}_{4}\right)_{3}-\mathrm{FeSO}_{4}-\mathrm{H}_{2} \mathrm{O}$ containing $\mathrm{Cu}^{2+}$, as shown previously, the nominal $\mathrm{H}_{2} \mathrm{SO}_{4}$ concentration in Figure 1 is $0.1 \mathrm{~mol} / \mathrm{L}$, corresponding to a nominal $\mathrm{pH}$ value of about 0.7 (the actual $\mathrm{pH}$ values of the solutions should be different based on the solution composition). And it seems that the co-existence of $\mathrm{Cu}^{2+}$ ion concentration up to 0.1 mol/L does not exert an obvious influence on the prediction of redox potentials by Eq. (1), in both of the data shown in Figure 1 and the present study. Based on the above analysis, it seems that Eq. (1) can be applied in a wide range of $\mathrm{pH}$, and there is almost no change in redox potential caused by $\mathrm{pH}$, even at $150^{\circ} \mathrm{C}$ when ferric is hydrolyzed to form hematite and release $\mathrm{H}^{+}$(Yue et al. 2014a). In the present work, as shown in Tables 3, 4 and 6 (bioleaching tests), although the $\mathrm{pH}$ changes during leaching, in general it seems that Eq. (1) can be still used. Hence, it seems that the change of $\mathrm{pH}$ exerts almost no influence on Eq. (1), the relation between ORP and iron determination. However, admittedly, further research is required to support this, especially under even more complicated solution conditions. 
There are four kinds of error that may result in the disagreement between the measured and predicted redox potential: (1) the measured redox potential is in error, (2) the error associated with Eq. (1) itself, the nominal ferric/ferrous ratio determined by experiment (in the present study, by (3) AAS for the total iron determination, and by (4) cerium titration for the ferrous ion determination). As discussed in Section 3.1, the accuracy of the measured redox potential is easy to ensure. For the error associate with Eq. (1), as long as the employed nominal ferric/ferrous ratio is accurate, the accuracy of the predicted potential is acceptable. Hence, it seems that the determination of the nominal ferric/ferrous ratio is the most important factor in the present study. For the chemical analysis of total iron, ferric ion and ferrous ion, various methods have been discussed and compared by previously published papers (Karamanev et al., 2002; Paipa et al., 2005). Typically, these methods (colorimetric or volumetric measurement) involve the use of various chemicals (such as 1,10-phenanthroline, 5-sulfosalicylic acid, and potassium dichromate) and complicated procedures. There is also a detection limit for each of those methods, and interference exists when analyzing very complicated solutions. Please note that AAS can only be used to determine the total iron.

The present work not only provides a simple and easy method to determine trace amounts of ferrous in a ferric-dominant solution, but also a way to understand the iron chemistry in a ferrous-dominant solution only based on the measured redox potential, temperature and total iron by AAS (the detection limit is $0.1 \mathrm{mg} / \mathrm{L}$ and the experimental error is estimated to range between 3 and 5\%). In this way, the accuracy of the ferrous amount determined by cerium titration can also be checked to see whether the obtained result is reasonable or not. Considering the cost to determine the ferrous amount by titration or other methods, it is much more convenient to use Eq. (1) directly. Of course, before using this equation, some sort of validation for a particular solution chemistry should be performed.

\section{Conclusions}

In our previous work, an expression was developed to predict the redox potential of quaternary $\mathrm{H}_{2} \mathrm{SO}_{4}-\mathrm{Fe}_{2}\left(\mathrm{SO}_{4}\right)_{3}-\mathrm{FeSO}_{4}-\mathrm{H}_{2} \mathrm{O}$ system over a wide range of solution conditions. The present work was carried out to determine whether this expression can be used to predict 
the redox potential of the $\mathrm{Fe}^{3+} / \mathrm{Fe}^{2+}$ couple and how to use it to understand the iron chemistry in more complicated acidic iron sulfate system generated during the acidic leaching and bioleaching of PCBs. The solution contains copper ions, other metal ions and bacteria/oxygen in bioleaching solutions.

It was shown that in general, the previously proposed expression can still be used to predict the redox potential of the $\mathrm{Fe}^{3+} / \mathrm{Fe}^{2+}$ couple in the above-mentioned solutions based on the nominal ferric/ferrous ratio determined by experiments, even with a relatively large error for the experimental-determined nominal ferric/ferrous ratio. In addition, based on the measured redox potential and total iron determined by AAS, the expression can also be used to the determination of ferric and ferrous amount in these solutions, especially in a ferric-dominant or ferrous-dominant solution. For the extremely complicated solution, at least the equation provides a qualitative method to understand the iron chemistry. By this way, the use of various chemicals and complicated analysis procedure in traditional colorimetric or volumetric measurement can be avoided. Please note that when calculating the redox potential of the $\mathrm{Fe}^{3+} / \mathrm{Fe}^{2+}$ couple by Eq. (1) for comparison with the measured redox potential, the data agreement is very sensitive to the accuracy of the determination of nominal ferric/ferrous ratio at a given temperature, especially for the method used to determine the ferrous concentration. This results from the fact that at a given temperature the redox potential of the $\mathrm{Fe}^{3+} / \mathrm{Fe}^{2+}$ couple calculated by Eq. (1) is solely determined by the nominal ferric/ferrous ratio whose accuracy largely depends on the reliability of ferrous concentration measurement (compared with that of total iron measurement by AAS). The applicability of Eq. (1) in acidic iron sulfate solutions containing cupric ions was also supported by the experimental results in the literature. The measurement of the redox potential is very useful to estimate and understand the iron change of the industrial leaching process which can be related to kinetics of the dissolution reaction, ferric hydrolysis reaction as well as chemical or biochemical oxidation of ferrous to ferric. 


\section{Acknowledgements}

The authors acknowledge the financial support of SNC Lavalin, Xstrata, the Natural Sciences and Engineering Research Council of Canada (NSERC) and the Bureau de Recherches Géologiques et Minières (BRGM). The authors would also like to thank Mickael Beaulieu (BRGM), Dominique Breeze (BRGM), Kathy Bru (BRGM) and Jérôme Jacob (BRGM) for their technical support. 


\section{References}

Battaglia, F., Morin, D., Ollivier, P., 1994. Dissolution of cobaltiferrous pyrite by Thiobacillus ferrooxidans and Thiobacillus thiooxidans - factors influencing bacterial leaching efficiency. J. Biotechnol. 32, 11-16.

Casas, J.M., Crisóstomo, G., Cifuentes, L., 2005. Speciation of the $\mathrm{Fe}(\mathrm{II})-\mathrm{Fe}(\mathrm{III})-\mathrm{H}_{2} \mathrm{SO}_{4}-\mathrm{H}_{2} \mathrm{O}$ system at 25 and $50^{\circ} \mathrm{C}$. Hydrometallurgy $80,254-264$.

Cifuentes, L., Casas, J.M., Simpson, J., 2006. Temperature dependence of the speciation of copper and iron in acidic electrolytes. Chem. Eng. Res. Des. 84, 965-969.

d'Hugues, P., Battaglia-Brunet, F., Clarens, M., Morin, D., 2003. Microbial diversity of various metal-sulfides bioleaching cultures grown under different operating conditions using 16S-rDNA analysis. In: Tsezos, M., Remoudaki, E., Hatzikioseyian, A. (Eds.). International Biohydrometallurgy Symposium IBS 2003. Hellas, Athens, pp. 1313-1324

Dry, M.J, Bryson, A.W., 1988. Prediction of redox potential in concentrated iron sulphate solutions. Hydrometallurgy 21, 59-72.

Filippou, D., Demopoulos, G.P., Papangelakis, V.G., 1995. Hydrogen ion activities and species distribution in mixed-metal sulfate aqueous system. AIChE J. 41, 171-184.

Guezennec, A., Bru, K., Jacob, J., d'Hugues, P., 2015. Co-processing of sulfidic mining wastes and metal-rich post-consumer wastes by biohydrometallurgy. Miner. Eng. 75, 45-53.

Guezennec, A.G., Hanke, M., Chmielarz, A., Joulian, C., Ménard, Y., d’Hugues, P., 2014. Bio-hydrometallurgy: an alternative to pyrometallurgy for copper recovery in a polymineral concentrate. Proceedings of Hydrometallurgy 2014 Congress - June 22-25, Victoria, Canada.

Hiroyoshi, N., Kitagawa, H., Tsunekawa, M., 2008. Effect of solution composition on the optimum redox potential for chalcopyrite leaching in sulfuric acid solutions. Hydrometallurgy 91, 144-149.

Hiroyoshi, N., Miki, H., Hirajima, T., Tsunekawa, M., 2000. A model for ferrous-promoted chalcopyrite leaching. Hydrometallurgy 57, 31-38.

Jones, D.L., 1974. The leaching of chalcopyrite. Ph.D. Thesis. University of British Columbia, Vancouver, Canada. 
Karamanev, D.G., Nikolov, L.N., Mamatarkova, V., 2002. Rapid simultaneous quantitative determination of ferric and ferrous ions in drainage waters and similar solutions. Miner. Eng. 15, 341-346.

Li, J., Zhong, T.K., Wadsworth, M.E., 1992. Application of mixed potential theory in hydrometallurgy. Hydrometallurgy 29, 47-60.

Liu, H., Papangelakis, V.G., Alam, M.S., Singh, G., 2003. Solubility of hematite in $\mathrm{H}_{2} \mathrm{SO}_{4}$ solutions at 230-270C. Can. Metall. Q. 42, 199-207.

Nicol, M.J., 1993. The role of electrochemistry in hydrometallurgy. In: Hiskey, J.B., Warren, G.W. (Eds.), Hydrometallurgy: Fundamentals, Technology and Innovation. Salt Lake City, Utah: The Minerals, Metals and Materials Society of AIME, pp. 43-62.

Paipa, C., Mateo, M., Godoy, I., Poblete, E., Toral, M.I., Vargas, T., 2005. Comparative study of alternative methods for the simultaneous determination of $\mathrm{Fe}^{+3}$ and $\mathrm{Fe}^{+2}$ in leaching solutions and in acid mine drainages. Miner. Eng. 18, 1116-1119.

Papangelakis, V.G., Blakey, B.C., Liao, H., 1994. Hematite solubility in sulphate process solutions. In: Monhemius, A.J. (Eds.), Hydrometallurgy '94. Cambridge, England: Springer, Netherlands, pp. 159-175.

Paramguru, R.K., 2002. Electrochemical aspects in some of the hydrometallurgical processes. Miner. Process. Extr. Metall. Rev. 23, 65-100.

Paramguru, R.K., Ray, H.S., 1996. Use of polarization data for the study of initial dissolution behavior of semiconducting minerals. Miner. Process. Extr. Metall. Rev. 16, 63-87.

Peters, E., 1986. Leaching of sulfides (Chapter 26). In: Somasundaran, P. (Eds.). Advances in Mineral Processing. Littleton, CO: SME/AIME, pp. 445-462.

Posnjak, E., Merwin, H.E., 1922. The system, $\mathrm{Fe}_{2} \mathrm{O}_{3}-\mathrm{SO}_{3}-\mathrm{H}_{2} \mathrm{O}$. J. Am. Chem. Soc. 44, 1965-1994.

Power, G.P., Ritchie, I.M., 1981. Mixed potential measurements in the elucidation of corrosion mechanisms-I introductory theory. Electrochim. Acta. 26, 1073-1078.

Power, G.P., Staunton, W.P., Ritchie, I.M., 1982. Mixed potential measurements in the elucidation of corrosion mechanisms-II some measurements. Electrochim. Acta. 27, 165-169.

Reid, M., Papangelakis, V.G., 2006. New data on hematite solubility in sulphuric acid solutions from 130 to $270^{\circ}$ C. In: Dutrizac, J.E., Riveros, P.A. (Eds.). Iron Control Technologies. Proceedings of the Third 
International Symposium on Iron Control in Hydrometallurgy. Montreal, QC: CIM, Montreal, QC, pp. 673-686.

Sapieszko, R.S., Patel, R.C., Matljevlc, E., 1977. Ferric hydrous oxide sols. 2. Thermodynamics of aqueous hydroxo and sulfato ferric complexes. J. Phys. Chem. 81, 1061-1068.

Sasaki, K., Ootsuka, K., Tozawa, K., 1993. Equilibrium diagram in the system, $\mathrm{Fe}_{2} \mathrm{O}_{3}-\mathrm{SO}_{3}-\mathrm{H}_{2} \mathrm{O}$, at elevated Temperatures-Hydrometallurgical studies on hydrolysis of the ferric sulphate solutions at elevated temperatures (2nd Report). Shigen-to-Sozai 109, 871-877.

Schlesinger, M.E., King, M.J., Sole, K.C., Davenport, W.G., 2011. Extractive Metallurgy of Copper, fifth edit. Elsevier Ltd., Amsterdam.

Stipp, S.L., 1990. Speciation in the $\mathrm{Fe}(\mathrm{II})-\mathrm{Fe}(\mathrm{III})-\mathrm{SO}_{4}-\mathrm{H}_{2} \mathrm{O}$ system at $25^{\circ} \mathrm{C}$ and low pH: sensitivity of an equilibrium model to uncertainties. Environ. Sci. Technol. 24, 699-706.

Tozawa, K., Sasaki, K., 1986. Effect of coexisting sulphates on precipitation of ferric oxide from ferric sulphate solutions at elevated temperatures. In: Dutrizac, J.E., Monhemius, A.J. (Eds.). Iron Control in Hydrometallurgy. Toronto ON: Ellis Horwood Limited, Chichester, England, pp. 454-476.

Umetsu, Y., Tozawa, K., Sasaki, K., 1977. The hydrolysis of ferric sulphate solutions at elevated temperatures. Can. Metall. Q. 16, 111-117.

Yue, G., Zhao, L., Olvera, O.G., Asselin, E., 2014a. Speciation of the $\mathrm{H}_{2} \mathrm{SO}_{4}-\mathrm{Fe}_{2}\left(\mathrm{SO}_{4}\right)_{3}-\mathrm{FeSO}_{4}-\mathrm{H}_{2} \mathrm{O}$ system and development of an expression to predict the redox potential of the $\mathrm{Fe}^{3+} / \mathrm{Fe}^{2+}$ couple up to $150^{\circ} \mathrm{C}$. Hydrometallurgy 147-148, 196-209.

Yue, G., Asselin, E., 2014b. Kinetics of ferric ion reduction on chalcopyrite and its influence on leaching up to $150^{\circ} \mathrm{C}$. Electrochim. Acta. 146, 307-321.

Yue, G., 2015. Speciation of the sulfuric acid-ferric sulfate-ferrous sulfate-water system and its application to chalcopyrite leaching kinetics up to $150^{\circ} \mathrm{C}$. Ph.D. Thesis. University of British Columbia, Vancouver, Canada.

Zembura, Z., 1968. Relationship between metallic corrosion and limiting current using the rotating disk method. Corros. Sci. 8,703-713. 


\section{List of Figures}

Fig. 1. Comparison of the potentials predicted by the expression in this work and measured by experiments in the $\mathrm{Fe}(\mathrm{II})-\mathrm{Fe}(\mathrm{III})-\mathrm{H}_{2} \mathrm{SO}_{4}$ solutions containing cupric ions from Hiroyoshi et al. (2000 and 2008) with different nominal ferric/ferrous ratios at room temperature. Detailed information on the nominal concentrations of $\mathrm{H}_{2} \mathrm{SO}_{4}, \mathrm{Fe}^{3+}, \mathrm{Fe}^{2+}$ and $\mathrm{Cu}^{2+}$ can be found in the literature. 


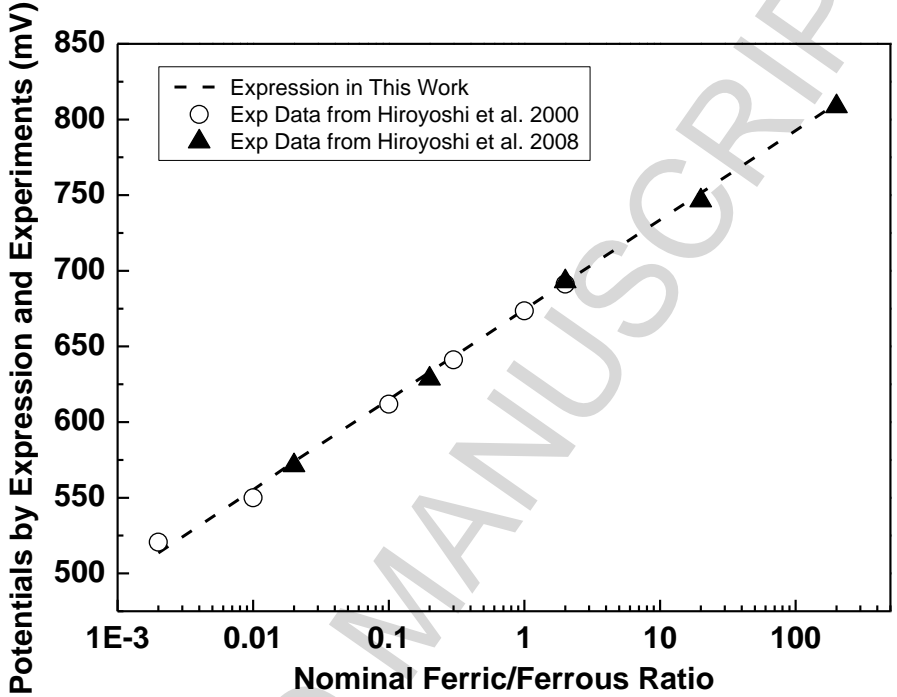

Fig. 1. Comparison of the potentials predicted by the expression in this work and measured by experiments in the $\mathrm{Fe}(\mathrm{II})-\mathrm{Fe}(\mathrm{III})-\mathrm{H}_{2} \mathrm{SO}_{4}$ solutions containing cupric ions from Hiroyoshi et al. (2000 and 2008) with different nominal ferric/ferrous ratios at room temperature. Detailed information on the nominal concentrations of $\mathrm{H}_{2} \mathrm{SO}_{4}, \mathrm{Fe}^{3+}, \mathrm{Fe}^{2+}$ and $\mathrm{Cu}^{2+}$ can be found in the literature. 
Table 1 Composition of the synthetic and biogenic lixiviant solutions.

Table 2 Calculated redox potentials by Eq. (1) in the $\mathrm{Fe}$ (II)- $\mathrm{Fe}$ (III)- $\mathrm{H}_{2} \mathrm{SO}_{4}$ solutions at $25^{\circ} \mathrm{C}$ and $40^{\circ} \mathrm{C}$ with different nominal ferric/ferrous ratios. The assumed errors for nominal ferric/ferrous ratios are $2 \%, 5 \%, 10 \%, 15 \%$ and $20 \%$, respectively.

Table 3 Results for the solution generated by acidic leaching of PCBs samples $(<750$ $\mu \mathrm{m})$ at room temperature with an initial solid load of $2.5 \%$ in shaking flask (containing $400 \mathrm{~mL}$ of a synthetic lixiviant solution including $\mathrm{Fe}^{3+}$ and $\mathrm{H}_{2} \mathrm{SO}_{4}$ without bacteria). The initial concentration of $\mathrm{Fe}^{3+}$ was $\sim 18 \mathrm{~g} / \mathrm{L}$.

Table 4 Results for the solution generated by acidic leaching of PCBs samples $(<750$ $\mu \mathrm{m})$ at room temperature with an initial solid load of $2.5 \%$ in shaking flask (containing $400 \mathrm{~mL}$ of a synthetic lixiviant solution including $\mathrm{Fe}^{3+}$ and $\mathrm{H}_{2} \mathrm{SO}_{4}$ without bacteria). The initial concentration of $\mathrm{Fe}^{3+}$ was $\sim 13 \mathrm{~g} / \mathrm{L}$.

Table 5 Results for the solution generated by bioleaching of PCBs samples $(<750 \mu \mathrm{m})$ at room temperature with an initial solid load of $2.5 \%$ in shaking flask (containing $400 \mathrm{~mL}$ of the biogenic lixiviant solution produced from the bioleaching of mining wastes). The initial concentration of $\mathrm{Fe}^{3+}$ was $\sim 18 \mathrm{~g} / \mathrm{L}$.

Table 6 Results for the solution generated by bioleaching of PCBs samples $(<750 \mu \mathrm{m})$ at about $40^{\circ} \mathrm{C}$ with an initial solid load of $2.5 \%$ in a stirred tank reactor $(300 \mathrm{rpm}$, containing $1 \mathrm{~L}$ of the biogenic lixiviant solution). The air flow rate was $0.5 \mathrm{~L} / \mathrm{h}$. The initial concentration of $\mathrm{Fe}^{3+}$ was $\sim 18 \mathrm{~g} / \mathrm{L}$. 
Table 1 Composition of the synthetic and biogenic lixiviant solutions.

\begin{tabular}{c|c|ccccc}
\hline \multicolumn{2}{c|}{} & & $E_{\mathrm{h}}$ & $\mathrm{Fe}_{\mathrm{tot}}$ & $\mathrm{Fe}^{2+}$ & $\mathrm{Cu}^{2+}$ \\
\multicolumn{2}{c}{ Type of PCB leaching test } & $\mathrm{pH}$ & $\mathrm{mV}$ & $\mathrm{g} / \mathrm{L}$ & $\mathrm{mg} / \mathrm{L}$ & $\mathrm{mg} / \mathrm{L}$ \\
\hline \multirow{2}{*}{$\begin{array}{c}\text { Shaking flasks } \\
(500 \mathrm{~mL})\end{array}$} & Synthetic solution & 1.49 & 910 & 12.85 & $\mathrm{n} . \mathrm{d}$. & \\
\cline { 3 - 7 } & & 1.38 & 914 & 17.3 & n. d. & \\
\cline { 2 - 7 } & Biogenic solution & 1.19 & 836 & 18.32 & 42 & 135 \\
\hline Reactor (1 L) & Biogenic solution & 0.9 & 799.6 & 18.43 & 151 & 112 \\
\hline
\end{tabular}

a. The experimental potentials from the $\operatorname{BRGM}\left(E_{\mathrm{h}}\right)$ shown in the table are the corrected values equal to the sum of $E_{\mathrm{obs}}$ and $E_{\mathrm{Ag} / \mathrm{AgCl}}(\mathrm{T})$ shown in Eq. (3). 
Table 2 Calculated redox potentials by Eq. (1) in the $\mathrm{Fe}(\mathrm{II})-\mathrm{Fe}(\mathrm{III})-\mathrm{H}_{2} \mathrm{SO}_{4}$ solutions at $25^{\circ} \mathrm{C}$ and $40^{\circ} \mathrm{C}$ with different nominal ferric/ferrous ratios. The assumed errors for nominal ferric/ferrous ratios are $2 \%, 5 \%, 10 \%, 15 \%$ and $20 \%$, respectively.

\begin{tabular}{|c|c|c|c|c|c|c|c|c|c|c|c|c|}
\hline \multirow{2}{*}{$\begin{array}{l}\mathrm{Fe}^{3+} / \mathrm{Fe}^{2+} \\
\text { (Nominal) }\end{array}$} & \multicolumn{6}{|c|}{ Calculated Redox Potential by Eq. (1) at $25^{\circ} \mathrm{C}(\mathrm{mV})$} & \multicolumn{6}{|c|}{ Calculated Redox Potential by Eq. (1) at $40{ }^{\circ} \mathrm{C}(\mathrm{mV})$} \\
\hline & $\begin{array}{c}E \\
\text { (Calc) }\end{array}$ & $\begin{array}{c}\Delta E_{1} \\
(1.02 / 0.98)\end{array}$ & $\begin{array}{c}\Delta E_{2} \\
(1.05 / 0.95)\end{array}$ & $\begin{array}{c}\Delta E_{3} \\
(1.10 / 0.90)\end{array}$ & $\begin{array}{c}\Delta E_{4} \\
(1.15 / 0.85)\end{array}$ & $\begin{array}{c}\Delta E_{5} \\
(1.20 / 0.80)\end{array}$ & $\begin{array}{c}E \\
\text { (Calc) }\end{array}$ & $\begin{array}{c}\Delta E_{6} \\
(1.02 / 0.98)\end{array}$ & $\begin{array}{c}\Delta E_{7} \\
(1.05 / 0.95)\end{array}$ & $\begin{array}{c}\Delta E_{8} \\
(1.10 / 0.90)\end{array}$ & $\begin{array}{c}\Delta E_{9} \\
(1.15 / 0.85)\end{array}$ & $\begin{array}{c}\Delta E_{10} \\
(1.20 / 0.80)\end{array}$ \\
\hline $0.001: 1$ & 496.92 & $0.51 /-0.52$ & $1.25 /-1.32$ & $2.45 /-2.71$ & $3.59 /-4.18$ & $4.68 /-5.73$ & 492.47 & $0.53 /-0.55$ & $1.32 /-1.38$ & $2.57 /-2.84$ & $3.77 /-4.39$ & $4.92 /-6.02$ \\
\hline $0.01: 1$ & 556.09 & $0.51 /-0.52$ & $1.25 /-1.32$ & $2.45 /-2.71$ & $3.59 /-4.18$ & $4.68 /-5.73$ & 554.62 & $0.53 /-0.55$ & $1.32 /-1.38$ & $2.57 /-2.84$ & $3.77 /-4.39$ & $4.92 /-6.02$ \\
\hline $0.1: 1$ & 615.26 & $0.51 /-0.52$ & $1.25 /-1.32$ & $2.45 /-2.71$ & $3.59 /-4.18$ & $4.68 /-5.73$ & 616.76 & $0.53 /-0.55$ & $1.32 /-1.38$ & $2.57 /-2.84$ & $3.77 /-4.39$ & $4.92 /-6.02$ \\
\hline $1: 1$ & 674.42 & $0.51 /-0.52$ & $1.25 /-1.32$ & $2.45 /-2.71$ & $3.59 /-4.18$ & $4.68 /-5.73$ & 678.90 & $0.53 /-0.55$ & $1.32 /-1.38$ & $2.57 /-2.84$ & $3.77 /-4.39$ & $4.92 /-6.02$ \\
\hline 10:1 & 733.59 & $0.51 /-0.52$ & $1.25 /-1.32$ & $2.45 /-2.71$ & $3.59 /-4.18$ & $4.68 /-5.73$ & 741.05 & $0.53 /-0.55$ & $1.32 /-1.38$ & $2.57 /-2.84$ & $3.77 /-4.39$ & $4.92 /-6.02$ \\
\hline 100:1 & 792.76 & $0.51 /-0.52$ & $1.25 /-1.32$ & $2.45 /-2.71$ & $3.59 /-4.18$ & $4.68 /-5.73$ & 803.19 & $0.53 /-0.55$ & $1.32 /-1.38$ & $2.57 /-2.84$ & $3.77 /-4.39$ & $4.92 /-6.02$ \\
\hline 1000:1 & 851.92 & $0.51 /-0.52$ & $1.25 /-1.32$ & $2.45 /-2.71$ & 18 & $4.68 /-5.73$ & 865.33 & $0.53 /-0.55$ & $1.32 /-1.38$ & $2.57 /-2.84$ & $3.77 /-4.39$ & $4.92 /-6.02$ \\
\hline
\end{tabular}


Table 3 Results for the solution generated by acidic leaching of PCBs samples $(<750$ $\mu \mathrm{m})$ at room temperature with an initial solid load of $2.5 \%$ in shaking flask (containing $400 \mathrm{~mL}$ of a synthetic lixiviant solution including $\mathrm{Fe}^{3+}$ and $\mathrm{H}_{2} \mathrm{SO}_{4}$ without bacteria). The initial concentration of $\mathrm{Fe}^{3+}$ was $\sim 18 \mathrm{~g} / \mathrm{L}$.

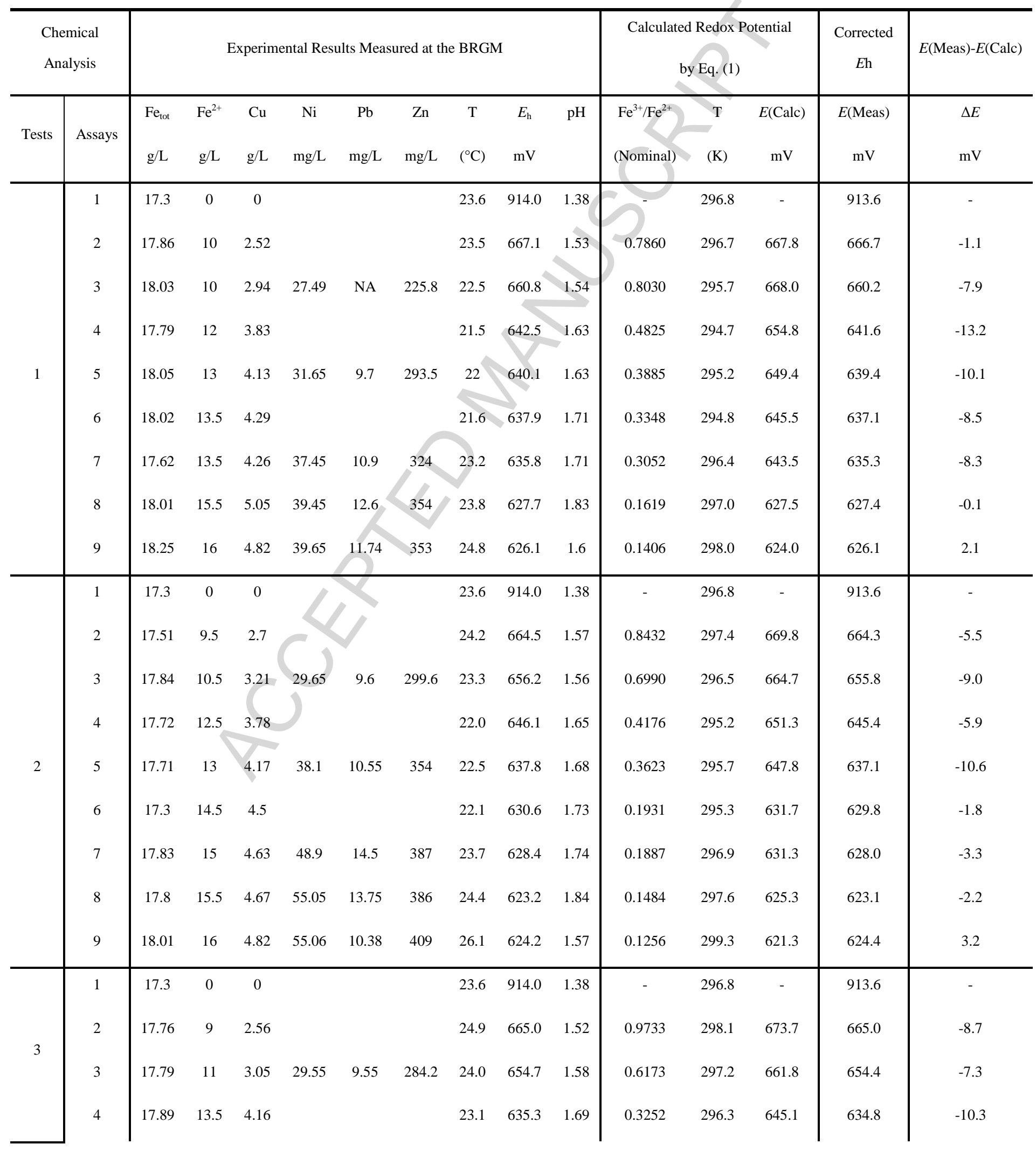




\begin{tabular}{|c|c|c|c|c|c|c|c|c|c|c|c|c|c|}
\hline 17.84 & 14 & 4.45 & 36.9 & 10.4 & 375.5 & 23.5 & 631.0 & 1.70 & 0.2743 & 296.7 & 640.9 & 630.6 & -10.2 \\
\hline 17.3 & 15 & 4.58 & & & & 23.3 & 625.7 & 1.73 & 0.1533 & 296.5 & 626.0 & 625.2 & -0.7 \\
\hline 17.95 & 15.5 & 4.69 & 42.85 & 13.15 & 398 & 24.6 & 623.7 & 1.74 & 0.1581 & 297.8 & 627.0 & 623.6 & -3.4 \\
\hline 18.06 & 16.5 & 4.63 & 46.7 & 17.35 & 412 & 25.4 & 613.5 & 1.89 & 0.0945 & 298.6 & 613.9 & 613.6 & -0.3 \\
\hline
\end{tabular}

a. The experimental potentials from the $\operatorname{BRGM}\left(E_{\mathrm{h}}\right)$ shown in the table are the corrected values equal to the sum of $E_{\mathrm{obs}}$ and $E_{\mathrm{Ag} / \mathrm{AgCl}}(\mathrm{T})$ shown in Eq. (3).

b. The corrected $E_{\mathrm{h}}$ are referred to the $\mathrm{SHE}$ at $25^{\circ} \mathrm{C}$.

Table 4 Results for the solution generated by acidic leaching of PCBs samples $(<750$ $\mu \mathrm{m})$ at room temperature with an initial solid load of $2.5 \%$ in shaking flask (containing $400 \mathrm{~mL}$ of a synthetic lixiviant solution including $\mathrm{Fe}^{3+}$ and $\mathrm{H}_{2} \mathrm{SO}_{4}$ without bacteria). The initial concentration of $\mathrm{Fe}^{3+}$ was $\sim 13 \mathrm{~g} / \mathrm{L}$.

\begin{tabular}{|c|c|c|c|c|c|c|c|c|c|c|c|c|c|c|c|}
\hline \multicolumn{2}{|c|}{$\begin{array}{l}\text { Chemical } \\
\text { Analysis }\end{array}$} & \multicolumn{9}{|c|}{ Experimental Results Measured at the BRGM } & \multicolumn{3}{|c|}{$\begin{array}{l}\text { Calculated Redox } \\
\text { Potential } \\
\text { by Eq. (1) }\end{array}$} & \multirow{2}{*}{$\begin{array}{c}\text { Corrected } \\
\text { Eh } \\
E \text { (Meas) }\end{array}$} & \multirow{2}{*}{$\begin{array}{c}E \text { (Meas) } E( \\
\text { Calc) } \\
\Delta E\end{array}$} \\
\hline \multirow[t]{2}{*}{$\begin{array}{c}\text { Test } \\
\mathrm{s}\end{array}$} & \multirow[t]{2}{*}{$\begin{array}{c}\text { Assay } \\
\text { s }\end{array}$} & $\mathrm{Fe}_{\text {tot }}$ & $\begin{array}{c}\mathrm{Fe}^{2} \\
+\end{array}$ & $\mathrm{Cu}$ & $\mathrm{Ni}$ & $\mathrm{Pb}$ & $\mathrm{Zn}$ & $\mathrm{T}$ & $E_{\mathrm{h}}$ & $\mathrm{pH}$ & $\begin{array}{c}\mathrm{Fe}^{3+} / \mathrm{Fe} \\
2+\end{array}$ & $\mathrm{T}$ & $\begin{array}{c}E(\mathrm{Cal} \\
\text { c) }\end{array}$ & & \\
\hline & & $\mathrm{g} / \mathrm{L}$ & $\begin{array}{l}\mathrm{g} / \\
\mathrm{L}\end{array}$ & $\mathrm{g} / \mathrm{L}$ & $\begin{array}{c}\mathrm{mg} / \\
\mathrm{L}\end{array}$ & $\begin{array}{c}\mathrm{mg} / \\
\mathrm{L}\end{array}$ & $\begin{array}{c}\mathrm{mg} / \\
\mathrm{L}\end{array}$ & $\begin{array}{l}\left(^{\circ}\right. \\
\mathrm{C})\end{array}$ & $\mathrm{mV}$ & & $\begin{array}{l}\text { (Nomin } \\
\text { al) }\end{array}$ & $(\mathrm{K})$ & $\mathrm{mV}$ & $\mathrm{mV}$ & $\mathrm{mV}$ \\
\hline \multirow[t]{6}{*}{1} & 1 & $\begin{array}{l}12 . \\
85\end{array}$ & 0 & 0 & & & & $\begin{array}{r}23 . \\
6\end{array}$ & $\begin{array}{r}910 \\
.0\end{array}$ & $\begin{array}{c}1.4 \\
9\end{array}$ & - & $\begin{array}{c}296 \\
.8\end{array}$ & - & 909.6 & - \\
\hline & 2 & $\begin{array}{l}13 . \\
24\end{array}$ & 8 & $\begin{array}{c}2.1 \\
8\end{array}$ & & & & $\begin{array}{c}24 . \\
1\end{array}$ & $\begin{array}{c}656 \\
.6\end{array}$ & $\begin{array}{c}1.6 \\
7\end{array}$ & 0.6550 & $\begin{array}{r}297 \\
.3\end{array}$ & 663.3 & 656.4 & -6.9 \\
\hline & 3 & $\begin{array}{c}13 . \\
1\end{array}$ & 9 & $\begin{array}{c}2.4 \\
1\end{array}$ & $\begin{array}{l}25 . \\
35\end{array}$ & 9.3 & $\begin{array}{c}216 \\
.6\end{array}$ & $\begin{array}{r}22 . \\
9\end{array}$ & $\begin{array}{r}648 \\
.5\end{array}$ & $\begin{array}{c}1.6 \\
8\end{array}$ & 0.4556 & $\begin{array}{c}296 \\
.1\end{array}$ & 653.7 & 648.0 & -5.7 \\
\hline & 4 & $\begin{array}{l}13 . \\
44\end{array}$ & $\begin{array}{c}11 . \\
5\end{array}$ & $\begin{array}{c}3.2 \\
9\end{array}$ & & & & $\begin{array}{r}21 . \\
8\end{array}$ & $\begin{array}{c}626 \\
.3\end{array}$ & $\begin{array}{c}1.7 \\
9\end{array}$ & 0.1687 & $\begin{array}{c}295 \\
.0\end{array}$ & 628.2 & 625.5 & -2.7 \\
\hline & 5 & $\begin{array}{l}12 . \\
86\end{array}$ & $\begin{array}{c}11 . \\
5\end{array}$ & $\begin{array}{c}3.4 \\
3\end{array}$ & 32 & 10 & 285 & $\begin{array}{c}22 . \\
2\end{array}$ & $\begin{array}{r}619 \\
.0\end{array}$ & $\begin{array}{c}1.8 \\
2\end{array}$ & 0.1183 & $\begin{array}{c}295 \\
.4\end{array}$ & 619.2 & 618.3 & -0.9 \\
\hline & 6 & 13. & 12. & 3.9 & & & & 21. & 599 & 1.8 & 0.0624 & 295 & 602.9 & 598.9 & -4.0 \\
\hline
\end{tabular}




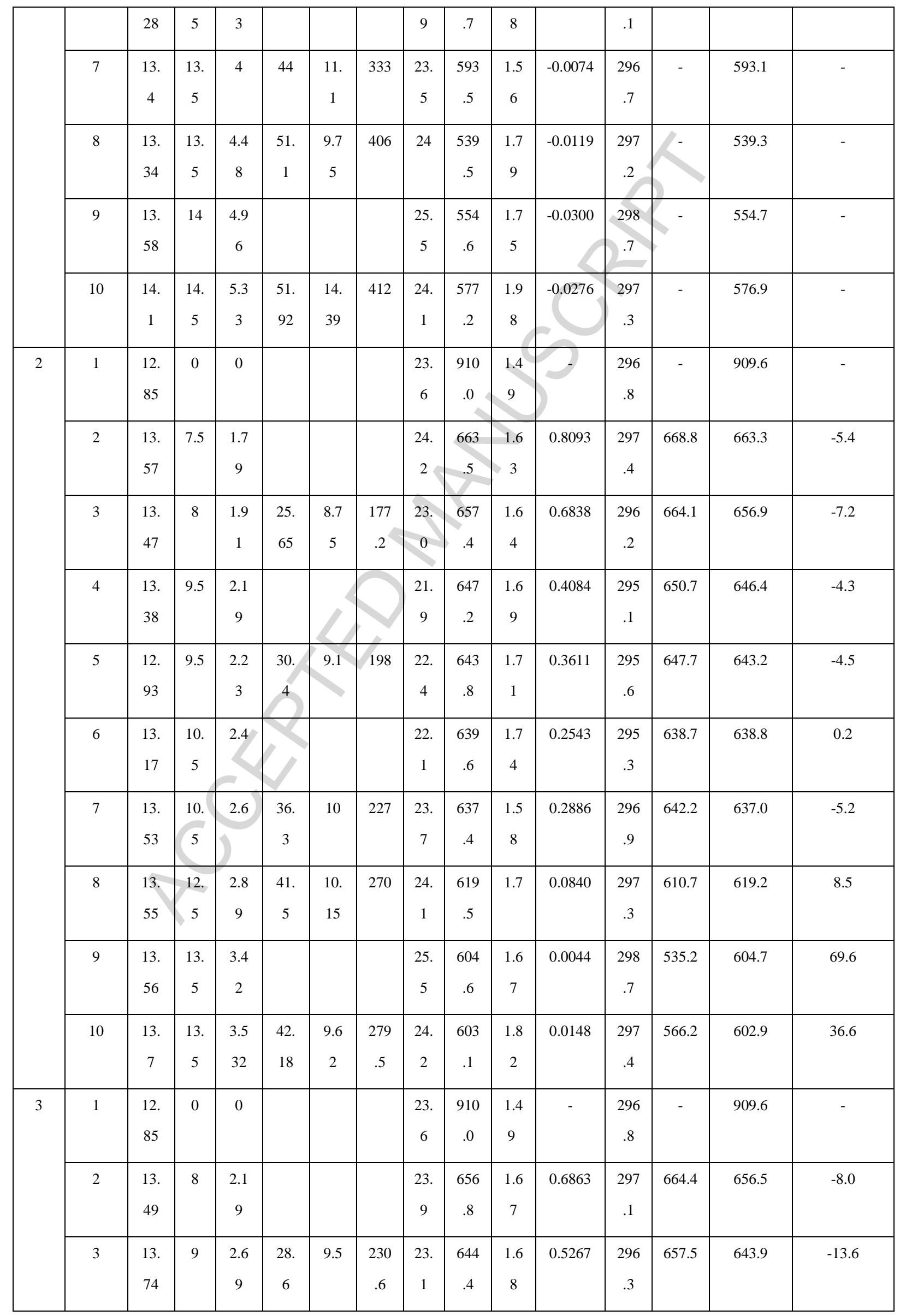




\begin{tabular}{|c|c|c|c|c|c|c|c|c|c|c|c|c|c|c|}
\hline 4 & $\begin{array}{l}13 . \\
31\end{array}$ & 11 & $\begin{array}{c}3.0 \\
9\end{array}$ & & & & $\begin{array}{c}22 . \\
1\end{array}$ & $\begin{array}{c}629 \\
.1\end{array}$ & $\begin{array}{c}1.7 \\
6\end{array}$ & 0.2100 & $\begin{array}{c}295 \\
.3\end{array}$ & 633.8 & 628.3 & -5.5 \\
\hline 5 & $\begin{array}{l}13 . \\
07\end{array}$ & 11 & $\begin{array}{c}3.1 \\
4\end{array}$ & $\begin{array}{c}35 . \\
4\end{array}$ & $\begin{array}{c}10 . \\
1\end{array}$ & $\begin{array}{c}252 \\
.5\end{array}$ & $\begin{array}{c}22 . \\
6\end{array}$ & $\begin{array}{c}624 \\
.7\end{array}$ & $\begin{array}{c}1.7 \\
8\end{array}$ & 0.1882 & $\begin{array}{c}295 \\
.8\end{array}$ & 631.1 & 624.1 & -7.0 \\
\hline 6 & $\begin{array}{l}13 . \\
19\end{array}$ & $\begin{array}{c}11 . \\
5\end{array}$ & $\begin{array}{c}3.2 \\
4\end{array}$ & & & & $\begin{array}{c}22 . \\
2\end{array}$ & $\begin{array}{c}621 \\
.5\end{array}$ & $\begin{array}{c}1.8 \\
1\end{array}$ & 0.1470 & $\begin{array}{r}295 \\
4\end{array}$ & 624.7 & 620.8 & -3.9 \\
\hline 7 & $\begin{array}{l}13 . \\
53\end{array}$ & 12 & $\begin{array}{c}3.3 \\
6\end{array}$ & $\begin{array}{l}41 . \\
75\end{array}$ & $\begin{array}{c}11 . \\
7\end{array}$ & 270 & $\begin{array}{c}23 . \\
7\end{array}$ & $\begin{array}{c}618 \\
.4\end{array}$ & $\begin{array}{c}1.5 \\
8\end{array}$ & 1075 & $\begin{array}{c}296 \\
.9\end{array}$ & 621.3 & 618.0 & -3.3 \\
\hline 8 & $\begin{array}{l}13 . \\
68\end{array}$ & 13 & $\begin{array}{c}3.4 \\
7\end{array}$ & $\begin{array}{l}44 . \\
75\end{array}$ & $\begin{array}{c}10 . \\
3\end{array}$ & 278 & $\begin{array}{c}24 . \\
3\end{array}$ & $\begin{array}{c}607 \\
.3\end{array}$ & $\begin{array}{c}1.7 \\
0\end{array}$ & 0.0523 & $\begin{array}{c}297 \\
.5\end{array}$ & 598.6 & 607.1 & 8.6 \\
\hline 9 & $\begin{array}{l}13 . \\
55\end{array}$ & 14 & $\begin{array}{c}4.2 \\
9\end{array}$ & & & & $\begin{array}{c}25 . \\
7\end{array}$ & $\begin{array}{c}563 \\
.5\end{array}$ & $\begin{array}{c}1.7 \\
7\end{array}$ & -0.0321 & $\begin{array}{c}298 \\
.9\end{array}$ & - & 563.6 & - \\
\hline 10 & $\begin{array}{l}13 . \\
65\end{array}$ & 14 & $\begin{array}{c}4.4 \\
2\end{array}$ & $\begin{array}{l}57 . \\
58\end{array}$ & 8.1 & 352 & $\begin{array}{c}24 . \\
2\end{array}$ & $\begin{array}{c}582 \\
.1\end{array}$ & $\begin{array}{c}1.9 \\
9\end{array}$ & -0.0250 & $\begin{array}{c}297 \\
.4\end{array}$ & - & 581.9 & - \\
\hline
\end{tabular}


Table 5 Results for the solution generated by bioleaching of PCBs samples $(<750 \mu \mathrm{m})$ at room temperature with an initial solid load of $2.5 \%$ in shaking flask (containing $400 \mathrm{~mL}$ of the biogenic lixiviant solution produced from the bioleaching of mining wastes). The initial concentration of $\mathrm{Fe}^{3+}$ was $\sim 18 \mathrm{~g} / \mathrm{L}$.

\begin{tabular}{|c|c|c|c|c|c|c|c|c|c|c|c|c|c|c|c|}
\hline \multicolumn{2}{|c|}{$\begin{array}{l}\text { Chemical } \\
\text { Analysis }\end{array}$} & \multicolumn{9}{|c|}{ Experimental Results Measured at the BRGM } & \multicolumn{3}{|c|}{$\begin{array}{c}\text { Calculated Redox } \\
\text { Potential }\end{array}$} & \multirow{2}{*}{$\begin{array}{c}\text { Corrected } \\
\qquad \mathrm{hh} \\
\text { E(Meas) }\end{array}$} & \multirow{2}{*}{$\begin{array}{c}E \text { (Meas)-E( } \\
\text { Calc) } \\
\Delta E\end{array}$} \\
\hline \multirow[t]{2}{*}{$\begin{array}{c}\text { Test } \\
\mathrm{s}\end{array}$} & \multirow[t]{2}{*}{$\begin{array}{c}\text { Assay } \\
\mathrm{s}\end{array}$} & $\mathrm{Fe}_{\text {tot }}$ & $\mathrm{Fe}^{2+}$ & $\mathrm{Cu}$ & $\mathrm{Ni}$ & $\mathrm{Pb}$ & $\mathrm{Zn}$ & $\mathrm{T}$ & $E_{\mathrm{h}}$ & $\mathrm{pH}$ & $\mathrm{Fe}^{3+} / \mathrm{Fe}$ & $\mathrm{T}$ & $\begin{array}{l}E(\mathrm{Cal} \\
\text { c) }\end{array}$ & & \\
\hline & & $\mathrm{g} / \mathrm{L}$ & $\mathrm{g} / \mathrm{L}$ & $\begin{array}{l}\mathrm{g} / \\
\mathrm{L}\end{array}$ & $\begin{array}{c}\mathrm{mg} / \\
\mathrm{L}\end{array}$ & $\begin{array}{c}\mathrm{mg} / \\
\mathrm{L}\end{array}$ & $\begin{array}{c}\mathrm{mg} / \\
\mathrm{L}\end{array}$ & $\begin{array}{l}{ }^{\circ} \\
\mathrm{C})\end{array}$ & $\mathrm{mV}$ & & (Nomin & $(\mathrm{K})$ & $\mathrm{mV}$ & $\mathrm{mV}$ & $\mathrm{mV}$ \\
\hline \multirow[t]{8}{*}{1} & 1 & $\begin{array}{l}18 . \\
32\end{array}$ & $\begin{array}{l}0.0 \\
42\end{array}$ & $\begin{array}{c}0.1 \\
4\end{array}$ & $\begin{array}{l}15 . \\
75\end{array}$ & 5.5 & 11 & $\begin{array}{c}22 . \\
4\end{array}$ & $\begin{array}{c}836 \\
.0\end{array}$ & $\begin{array}{c}1.1 \\
9\end{array}$ & 435.12 & $\begin{array}{c}295 \\
.6\end{array}$ & 828.4 & 835.3 & 6.98 \\
\hline & 2 & $\begin{array}{l}18 . \\
30\end{array}$ & $\begin{array}{c}7.5 \\
4\end{array}$ & $\begin{array}{c}1.8 \\
2\end{array}$ & 33 & $\begin{array}{c}12 . \\
5\end{array}$ & 119 & $\begin{array}{l}23 . \\
7\end{array}$ & $\begin{array}{l}706 \\
.1\end{array}$ & $\begin{array}{c}1.1 \\
9\end{array}$ & 1.4279 & $\begin{array}{c}296 \\
.9\end{array}$ & 683.1 & 705.7 & 22.6 \\
\hline & 3 & $\begin{array}{l}17 . \\
97\end{array}$ & $\begin{array}{c}9.6 \\
8\end{array}$ & $\begin{array}{c}3.0 \\
0\end{array}$ & 47 & 14 & 226. & $\begin{array}{c}24 . \\
7\end{array}$ & $\begin{array}{c}688 \\
.7\end{array}$ & $\begin{array}{c}1.2 \\
2\end{array}$ & 0.8576 & $\begin{array}{c}297 \\
.9\end{array}$ & 670.4 & 688.6 & 18.2 \\
\hline & 4 & $\begin{array}{l}17 . \\
83\end{array}$ & $\begin{array}{l}12 . \\
13\end{array}$ & $\begin{array}{c}3.8 \\
5\end{array}$ & $\begin{array}{l}43 . \\
75\end{array}$ & 15 & 301 & $\begin{array}{c}22 . \\
1\end{array}$ & $\begin{array}{c}674 \\
.7\end{array}$ & $\begin{array}{c}1.3 \\
2\end{array}$ & 0.4693 & $\begin{array}{c}295 \\
.3\end{array}$ & 654.3 & 674.0 & 19.7 \\
\hline & 5 & $\begin{array}{l}18 . \\
78\end{array}$ & $\begin{array}{l}12 . \\
29\end{array}$ & $\begin{array}{c}4.1 \\
0\end{array}$ & $\begin{array}{l}47 . \\
75\end{array}$ & $\begin{array}{l}13 . \\
75\end{array}$ & 329 & $\begin{array}{c}24 . \\
1\end{array}$ & $\begin{array}{c}668 \\
.4\end{array}$ & $\begin{array}{c}1.3 \\
1\end{array}$ & 0.5283 & $\begin{array}{c}297 \\
.3\end{array}$ & 657.8 & 668.2 & 10.4 \\
\hline & 6 & $\begin{array}{l}18 . \\
90\end{array}$ & $\begin{array}{l}12 . \\
36\end{array}$ & $\begin{array}{c}4.3 \\
5\end{array}$ & $\begin{array}{l}47 . \\
75\end{array}$ & $\begin{array}{c}15 . \\
5\end{array}$ & 325 & $\begin{array}{c}23 . \\
1\end{array}$ & $\begin{array}{c}675 \\
.7\end{array}$ & $\begin{array}{c}1.3 \\
5\end{array}$ & 0.5299 & $\begin{array}{c}296 \\
.3\end{array}$ & 657.6 & 675.2 & 17.6 \\
\hline & 7 & $\begin{array}{l}19 . \\
22\end{array}$ & $\begin{array}{l}12 . \\
65\end{array}$ & $\begin{array}{c}4.5 \\
3\end{array}$ & $\begin{array}{l}50 . \\
75\end{array}$ & $\begin{array}{c}15 . \\
5\end{array}$ & 332 & $\begin{array}{c}24 \\
2\end{array}$ & $\begin{array}{c}668 \\
.4\end{array}$ & $\begin{array}{c}1.3 \\
7\end{array}$ & 0.5197 & $\begin{array}{c}297 \\
.4\end{array}$ & 657.4 & 668.2 & 10.8 \\
\hline & 8 & $\begin{array}{l}20 . \\
15\end{array}$ & $\begin{array}{l}13 . \\
28\end{array}$ & $\begin{array}{c}5.1 \\
6\end{array}$ & 54 & 15 & 341 & $\begin{array}{c}22 . \\
6\end{array}$ & $\begin{array}{c}670 \\
.7\end{array}$ & $\begin{array}{c}1.4 \\
3\end{array}$ & 0.5177 & $\begin{array}{c}295 \\
.8\end{array}$ & 656.9 & 670.1 & 13.2 \\
\hline \multirow[t]{4}{*}{2} & 1 & $\begin{array}{l}18 . \\
32\end{array}$ & $\begin{array}{l}0.0 \\
42\end{array}$ & $\begin{array}{c}0.1 \\
4\end{array}$ & $\begin{array}{l}15 . \\
75\end{array}$ & 5.5 & 11 & $\begin{array}{c}22 . \\
5\end{array}$ & $\begin{array}{c}836 \\
.0\end{array}$ & $\begin{array}{c}1.1 \\
9\end{array}$ & 435.12 & $\begin{array}{c}295 \\
.7\end{array}$ & 828.4 & 835.4 & 6.92 \\
\hline & 2 & $\begin{array}{l}17 . \\
99\end{array}$ & $\begin{array}{c}8.2 \\
0\end{array}$ & $\begin{array}{c}1.9 \\
5\end{array}$ & $\begin{array}{l}33 . \\
75\end{array}$ & 13 & $\begin{array}{c}150 . \\
5\end{array}$ & $\begin{array}{c}24 . \\
0\end{array}$ & $\begin{array}{c}703 \\
.8\end{array}$ & 1.2 & 1.1953 & $\begin{array}{c}297 \\
.2\end{array}$ & 678.7 & 703.6 & 24.9 \\
\hline & 3 & $\begin{array}{l}18 . \\
32\end{array}$ & $\begin{array}{l}10 . \\
11\end{array}$ & $\begin{array}{c}2.7 \\
6\end{array}$ & 39 & $\begin{array}{l}13 . \\
75\end{array}$ & $\begin{array}{c}219 . \\
25\end{array}$ & $\begin{array}{c}25 . \\
1\end{array}$ & $\begin{array}{c}691 \\
.4\end{array}$ & $\begin{array}{c}1.2 \\
1\end{array}$ & 0.8116 & $\begin{array}{c}298 \\
.3\end{array}$ & 669.1 & 691.4 & 22.3 \\
\hline & 4 & $\begin{array}{l}18 . \\
39\end{array}$ & $\begin{array}{l}11 . \\
48\end{array}$ & $\begin{array}{c}3.7 \\
2\end{array}$ & $\begin{array}{l}45 . \\
75\end{array}$ & $\begin{array}{c}14 . \\
5\end{array}$ & $\begin{array}{c}292 . \\
5\end{array}$ & $\begin{array}{c}22 . \\
5\end{array}$ & $\begin{array}{c}674 \\
.4\end{array}$ & $\begin{array}{c}1.3 \\
2\end{array}$ & 0.6012 & $\begin{array}{c}295 \\
.7\end{array}$ & 660.7 & 673.8 & 13.1 \\
\hline
\end{tabular}




\begin{tabular}{|c|c|c|c|c|c|c|c|c|c|c|c|c|c|c|c|}
\hline & 5 & $\begin{array}{l}18 . \\
52\end{array}$ & $\begin{array}{l}12 . \\
29\end{array}$ & $\begin{array}{c}3.9 \\
4\end{array}$ & 48 & 14 & 308 & $\begin{array}{c}24 . \\
7\end{array}$ & $\begin{array}{c}667 \\
.0\end{array}$ & $\begin{array}{c}1.3 \\
1\end{array}$ & 0.5078 & $\begin{array}{c}297 \\
.9\end{array}$ & 656.9 & 666.9 & 10.0 \\
\hline & 6 & $\begin{array}{l}19 . \\
21\end{array}$ & $\begin{array}{l}12 . \\
78\end{array}$ & $\begin{array}{c}4.3 \\
6\end{array}$ & $\begin{array}{l}50 . \\
25\end{array}$ & 15 & 340 & $\begin{array}{c}23 . \\
7\end{array}$ & $\begin{array}{c}672 \\
.2\end{array}$ & $\begin{array}{c}1.3 \\
6\end{array}$ & 0.5031 & $\begin{array}{c}296 \\
.9\end{array}$ & 656.4 & 671.9 & 15.5 \\
\hline & 7 & $\begin{array}{l}19 . \\
10\end{array}$ & $\begin{array}{l}13 . \\
41\end{array}$ & $\begin{array}{c}4.7 \\
2\end{array}$ & 54 & $\begin{array}{l}15 . \\
25\end{array}$ & 366 & $\begin{array}{c}24 . \\
9\end{array}$ & $\begin{array}{c}661 \\
.9\end{array}$ & $\begin{array}{c}1.3 \\
8\end{array}$ & 0.4242 & 298 & 652.4 & 661.8 & 9.5 \\
\hline & 8 & $\begin{array}{l}18 . \\
82\end{array}$ & $\begin{array}{l}14 . \\
49\end{array}$ & $\begin{array}{c}5.3 \\
9\end{array}$ & $\begin{array}{c}59 . \\
5\end{array}$ & $\begin{array}{c}14 . \\
5\end{array}$ & 359 & $\begin{array}{c}22 . \\
9\end{array}$ & $\begin{array}{c}660 \\
.5\end{array}$ & $\begin{array}{c}1.4 \\
6\end{array}$ & 0.2986 & $\begin{array}{c}296 \\
.1\end{array}$ & 642.9 & 659.9 & 17.0 \\
\hline 3 & 1 & $\begin{array}{l}18 . \\
32\end{array}$ & $\begin{array}{l}0.0 \\
42\end{array}$ & $\begin{array}{c}0.1 \\
4\end{array}$ & $\begin{array}{l}15 . \\
75\end{array}$ & 5.5 & 11 & $\begin{array}{c}22 . \\
6\end{array}$ & $\begin{array}{c}836 \\
.0\end{array}$ & $\begin{array}{c}1.1 \\
9\end{array}$ & 435.12 & $\begin{array}{c}295 \\
.8\end{array}$ & 828.5 & 835.4 & 6.86 \\
\hline & 2 & $\begin{array}{l}17 . \\
87\end{array}$ & $\begin{array}{c}8.6 \\
6\end{array}$ & $\begin{array}{c}2.1 \\
9\end{array}$ & 40 & $\begin{array}{c}13 . \\
5\end{array}$ & 157 & $\begin{array}{c}23 . \\
7\end{array}$ & $\begin{array}{c}700 \\
.1\end{array}$ & $\begin{array}{c}1.2 \\
0\end{array}$ & 1.0633 & $\begin{array}{c}296 \\
.9\end{array}$ & 675.6 & 699.7 & 24.1 \\
\hline & 3 & $\begin{array}{l}18 . \\
10\end{array}$ & $\begin{array}{c}9.9 \\
4\end{array}$ & $\begin{array}{c}2.8 \\
0\end{array}$ & $\begin{array}{c}37 . \\
5\end{array}$ & $\begin{array}{l}13 . \\
75\end{array}$ & 212 & 24. & $\begin{array}{c}687 \\
.9\end{array}$ & $\begin{array}{c}1.2 \\
1\end{array}$ & 0.8212 & $\begin{array}{c}297 \\
.6\end{array}$ & 669.2 & 687.7 & 18.5 \\
\hline & 4 & $\begin{array}{l}17 . \\
93\end{array}$ & $\begin{array}{l}11 . \\
77\end{array}$ & $\begin{array}{c}3.8 \\
0\end{array}$ & $\begin{array}{c}54 . \\
5\end{array}$ & $\begin{array}{c}14 . \\
5\end{array}$ & 274 & $\begin{array}{l}22 . \\
2\end{array}$ & $\begin{array}{c}673 \\
.6\end{array}$ & $\begin{array}{c}1.3 \\
3\end{array}$ & 0.5229 & $\begin{array}{r}295 \\
.4\end{array}$ & 657.0 & 672.9 & 15.9 \\
\hline & 5 & $\begin{array}{l}18 . \\
78\end{array}$ & $\begin{array}{l}12 . \\
42\end{array}$ & $\begin{array}{c}4.1 \\
8\end{array}$ & $\begin{array}{l}57 . \\
75\end{array}$ & $\begin{array}{l}14 . \\
25\end{array}$ & 295 & $\begin{array}{c}24 . \\
2\end{array}$ & $\begin{array}{c}666 \\
.4\end{array}$ & $\begin{array}{c}1.3 \\
2\end{array}$ & 0.5117 & $\begin{array}{r}297 \\
.4\end{array}$ & 657.0 & 666.2 & 9.2 \\
\hline & 6 & $\begin{array}{l}18 . \\
90\end{array}$ & $\begin{array}{l}12 . \\
85\end{array}$ & $\begin{array}{c}4.4 \\
7\end{array}$ & $\begin{array}{l}61 . \\
25\end{array}$ & $\begin{array}{l}14 . \\
75\end{array}$ & 320 & $\begin{array}{c}23 . \\
3\end{array}$ & $\begin{array}{c}671 \\
.5\end{array}$ & $\begin{array}{c}1.3 \\
6\end{array}$ & 0.4706 & $\begin{array}{c}296 \\
.5\end{array}$ & 654.6 & 671.1 & 16.5 \\
\hline & 7 & $\begin{array}{l}19 . \\
22\end{array}$ & $\begin{array}{l}13 . \\
68\end{array}$ & $\begin{array}{c}5.2 \\
1\end{array}$ & 68 & 15 & 343 & $\begin{array}{c}24 . \\
2\end{array}$ & $\begin{array}{c}658 \\
.4\end{array}$ & $\begin{array}{c}1.3 \\
8\end{array}$ & 0.4048 & $\begin{array}{r}297 \\
.4\end{array}$ & 651.0 & 658.2 & 7.2 \\
\hline & 8 & $\begin{array}{l}18 . \\
43\end{array}$ & $\begin{array}{l}14 . \\
13\end{array}$ & $\begin{array}{c}5.1 \\
9\end{array}$ & $\begin{array}{l}69 . \\
75\end{array}$ & $\begin{array}{l}14 . \\
25\end{array}$ & 328 & $\begin{array}{c}22 . \\
7\end{array}$ & $\begin{array}{c}660 \\
.6\end{array}$ & $\begin{array}{c}1.4 \\
6\end{array}$ & 0.3044 & $\begin{array}{c}295 \\
.9\end{array}$ & 643.4 & 660.0 & 16.7 \\
\hline
\end{tabular}


Table 6 Results for the solution generated by bioleaching of PCBs samples $(<750 \mu \mathrm{m})$ at about $40^{\circ} \mathrm{C}$ with an initial solid load of $2.5 \%$ in a stirred tank reactor $(300 \mathrm{rpm}$, containing $1 \mathrm{~L}$ of the biogenic lixiviant solution). The air flow rate was $0.5 \mathrm{~L} / \mathrm{h}$. The initial concentration of $\mathrm{Fe}^{3+}$ was $\sim 18 \mathrm{~g} / \mathrm{L}$.

\begin{tabular}{|c|c|c|c|c|c|c|c|c|c|c|c|c|c|c|c|}
\hline \multicolumn{2}{|c|}{$\begin{array}{l}\text { Chemical } \\
\text { Analysis }\end{array}$} & \multicolumn{9}{|c|}{ Experimental Results Measured at the BRGM } & \multicolumn{3}{|c|}{$\begin{array}{c}\text { Calculated Redox } \\
\text { Potential }\end{array}$} & \multirow{2}{*}{$\begin{array}{c}\text { Corrected } \\
\text { Eh } \\
E \text { (Meas) }\end{array}$} & \multirow{2}{*}{$\begin{array}{c}E \text { (Meas) }-E(\mathrm{C} \\
\text { alc) } \\
\Delta E\end{array}$} \\
\hline \multirow[t]{2}{*}{ Tests } & \multirow[t]{2}{*}{$\begin{array}{c}\text { Assay } \\
\mathrm{s}\end{array}$} & $\mathrm{Fe}_{\mathrm{tot}}$ & $\begin{array}{c}\mathrm{Fe}^{2} \\
+\end{array}$ & $\mathrm{Cu}$ & $\mathrm{Ni}$ & $\mathrm{Pb}$ & $\mathrm{Zn}$ & $\mathrm{T}$ & $E_{\mathrm{h}}$ & $\mathrm{pH}$ & $\mathrm{Fe}^{3+} / \mathrm{Fe}^{2}$ & $\mathrm{~T}$ & $\begin{array}{c}E(\mathrm{Cal} \\
\text { c) }\end{array}$ & & \\
\hline & & $\mathrm{g} / \mathrm{L}$ & $\begin{array}{l}\mathrm{g} / \\
\mathrm{L}\end{array}$ & $\begin{array}{l}\mathrm{g} / \\
\mathrm{L}\end{array}$ & $\begin{array}{c}\mathrm{mg} / \\
\mathrm{L}\end{array}$ & $\begin{array}{c}\mathrm{mg} / \\
\mathrm{L}\end{array}$ & $\begin{array}{c}\mathrm{mg} / \\
\mathrm{L}\end{array}$ & $\begin{array}{l}{ }^{\circ} \\
\mathrm{C})\end{array}$ & $\mathrm{mV}$ & 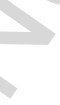 & $\begin{array}{l}\text { (Nomin } \\
\text { al) }\end{array}$ & $(\mathrm{K})$ & $\mathrm{mV}$ & $\mathrm{mV}$ & $\mathrm{mV}$ \\
\hline \multirow[t]{8}{*}{1} & 1 & $\begin{array}{c}18.4 \\
3\end{array}$ & $\begin{array}{c}0.1 \\
5\end{array}$ & & & & & & $\begin{array}{c}799 . \\
6\end{array}$ & 0.9 & 121.24 & $\begin{array}{c}273 . \\
2\end{array}$ & 778.9 & 811.5 & 32.6 \\
\hline & 2 & $\begin{array}{c}20.3 \\
3\end{array}$ & $\begin{array}{c}9.8 \\
9\end{array}$ & $\begin{array}{c}4.4 \\
1\end{array}$ & $\begin{array}{c}57.2 \\
5\end{array}$ & 15 & 330 & $\begin{array}{c}40 . \\
1\end{array}$ & $\begin{array}{c}665 . \\
3\end{array}$ & $\begin{array}{c}1.1 \\
2\end{array}$ & 1.0566 & $\begin{array}{c}313 . \\
3\end{array}$ & 680.4 & 669.2 & -11.2 \\
\hline & 3 & $\begin{array}{c}20.3 \\
5\end{array}$ & $\begin{array}{c}9.9 \\
0\end{array}$ & $\begin{array}{c}4.8 \\
1\end{array}$ & 61 & 14 & 350 & $\begin{array}{c}40 . \\
1\end{array}$ & $\begin{array}{c}665 . \\
3\end{array}$ & $\begin{array}{c}1.1 \\
9\end{array}$ & 1.0559 & $\begin{array}{c}313 . \\
3\end{array}$ & 680.4 & 669.2 & -11.2 \\
\hline & 4 & $\begin{array}{c}19.7 \\
8\end{array}$ & $\begin{array}{c}8.1 \\
6\end{array}$ & $\begin{array}{c}5.5 \\
9 \\
\end{array}$ & $\begin{array}{c}65.7 \\
5\end{array}$ & 22 & 400 & $\begin{array}{c}40 . \\
1\end{array}$ & $\begin{array}{c}674 . \\
4\end{array}$ & $\begin{array}{c}1.4 \\
2\end{array}$ & 1.4239 & $\begin{array}{c}313 . \\
3\end{array}$ & 688.5 & 678.3 & -10.2 \\
\hline & 5 & $\begin{array}{c}20.4 \\
2\end{array}$ & $\begin{array}{l}7.7 \\
7\end{array}$ & $\begin{array}{c}6.0 \\
3\end{array}$ & $\begin{array}{c}69.7 \\
5\end{array}$ & 13 & 400 & 40 & $\begin{array}{c}678 . \\
4\end{array}$ & $\begin{array}{c}1.4 \\
5\end{array}$ & 1.6287 & $\begin{array}{c}313 . \\
2\end{array}$ & 692.1 & 682.3 & -9.8 \\
\hline & 6 & $\begin{array}{c}18.9 \\
3\end{array}$ & $\begin{array}{c}7.9 \\
7\end{array}$ & $\begin{array}{c}5.6 \\
8\end{array}$ & 68 & $\begin{array}{c}22.7 \\
5\end{array}$ & 380 & $\begin{array}{c}39 . \\
9\end{array}$ & $\begin{array}{c}682 . \\
2\end{array}$ & $\begin{array}{c}1.5 \\
1\end{array}$ & 1.3756 & $\begin{array}{c}313 . \\
1\end{array}$ & 687.5 & 686.1 & -1.4 \\
\hline & 7 & $\begin{array}{c}19.6 \\
2\end{array}$ & $\begin{array}{c}7.5 \\
1\end{array}$ & $\begin{array}{c}5.9 \\
9\end{array}$ & 71 & $\begin{array}{c}15.7 \\
5\end{array}$ & 400 & $\begin{array}{c}40 . \\
3\end{array}$ & $\begin{array}{c}682 . \\
7\end{array}$ & $\begin{array}{c}1.4 \\
7\end{array}$ & 1.6118 & $\begin{array}{c}313 . \\
5\end{array}$ & 691.9 & 686.6 & -5.3 \\
\hline & 8 & 18.3 & $\begin{array}{c}6.7 \\
7\end{array}$ & 5.7 & $\begin{array}{c}66.7 \\
5\end{array}$ & 14.5 & 380 & 40 & $\begin{array}{c}679 . \\
8\end{array}$ & 1.5 & 1.7027 & $\begin{array}{c}313 . \\
2\end{array}$ & 693.3 & 683.6 & -9.6 \\
\hline \multirow[t]{3}{*}{2} & 1 & $\begin{array}{c}18.4 \\
3\end{array}$ & $\begin{array}{c}0.1 \\
5\end{array}$ & & & & & & $\begin{array}{c}799 . \\
6\end{array}$ & 0.9 & 121.24 & $\begin{array}{c}273 . \\
2\end{array}$ & 778.9 & 811.5 & 32.6 \\
\hline & 2 & 19.4 & $\begin{array}{c}8.6 \\
2\end{array}$ & $\begin{array}{c}3.3 \\
4\end{array}$ & 55.5 & 16 & 220 & $\begin{array}{c}39 . \\
8\end{array}$ & $\begin{array}{c}671 . \\
5\end{array}$ & $\begin{array}{c}1.0 \\
8\end{array}$ & 1.2514 & $\begin{array}{c}313 . \\
0\end{array}$ & 684.9 & 675.4 & -9.5 \\
\hline & 3 & $\begin{array}{c}21.4 \\
8\end{array}$ & $\begin{array}{c}9.0 \\
8\end{array}$ & $\begin{array}{c}4.4 \\
9\end{array}$ & 62.5 & 16.5 & 310 & $\begin{array}{c}39 . \\
8\end{array}$ & $\begin{array}{c}665 . \\
5\end{array}$ & $\begin{array}{c}1.1 \\
5\end{array}$ & 1.3649 & $\begin{array}{c}313 . \\
0\end{array}$ & 687.2 & 669.4 & -17.9 \\
\hline
\end{tabular}




\begin{tabular}{|c|c|c|c|c|c|c|c|c|c|c|c|c|c|c|}
\hline 4 & $\begin{array}{c}19.6 \\
8\end{array}$ & $\begin{array}{c}8.9 \\
6\end{array}$ & $\begin{array}{c}4.9 \\
3\end{array}$ & 70.5 & $\begin{array}{c}21.2 \\
5\end{array}$ & 330 & $\begin{array}{c}39 . \\
8\end{array}$ & $\begin{array}{c}670 . \\
6\end{array}$ & $\begin{array}{c}1.3 \\
2\end{array}$ & 1.1962 & $\begin{array}{c}313 . \\
0\end{array}$ & 683.7 & 674.5 & -9.2 \\
\hline 5 & $\begin{array}{c}19.2 \\
1\end{array}$ & $\begin{array}{c}8.6 \\
2\end{array}$ & 5.1 & 73.5 & $\begin{array}{c}12.2 \\
5\end{array}$ & 330 & $\begin{array}{c}39 . \\
8\end{array}$ & $\begin{array}{c}673 . \\
6\end{array}$ & 1.4 & 1.2280 & $\begin{array}{c}313 . \\
0\end{array}$ & 684.4 & 677.4 & -7.0 \\
\hline 6 & $\begin{array}{c}19.5 \\
1\end{array}$ & $\begin{array}{c}8.6 \\
6\end{array}$ & $\begin{array}{c}5.2 \\
1\end{array}$ & $\begin{array}{c}73.7 \\
5\end{array}$ & 23 & 340 & $\begin{array}{c}39 . \\
8\end{array}$ & $\begin{array}{c}678 . \\
3\end{array}$ & $\begin{array}{c}1.4 \\
1\end{array}$ & 1.2526 & 313. & 684.9 & 682.1 & -2.8 \\
\hline 7 & $\begin{array}{c}20.2 \\
5\end{array}$ & $\begin{array}{c}8.8 \\
7\end{array}$ & $\begin{array}{c}5.6 \\
4\end{array}$ & $\begin{array}{c}78.2 \\
5\end{array}$ & 15.5 & 370 & $\begin{array}{c}40 . \\
1\end{array}$ & $\begin{array}{c}676 . \\
8\end{array}$ & 1.4 & & $\begin{array}{c}313 . \\
3\end{array}$ & 685.6 & 680.7 & -4.9 \\
\hline 8 & $\begin{array}{c}18.6 \\
1\end{array}$ & $\begin{array}{r}7.7 \\
6\end{array}$ & $\begin{array}{c}5.2 \\
4\end{array}$ & 72.5 & $\begin{array}{c}15.2 \\
5\end{array}$ & 340 & $\begin{array}{c}39 . \\
9\end{array}$ & $\begin{array}{c}678 . \\
7\end{array}$ & $\begin{array}{c}1.4 \\
5\end{array}$ & 1.3974 & $\begin{array}{c}313 . \\
1\end{array}$ & 687.9 & 682.5 & -5.4 \\
\hline 9 & $\begin{array}{c}18.9 \\
8\end{array}$ & $\begin{array}{c}7.3 \\
3\end{array}$ & $\begin{array}{c}5.3 \\
7\end{array}$ & $\begin{array}{c}73.2 \\
5\end{array}$ & 15.5 & 350 & $\begin{array}{c}39 . \\
8\end{array}$ & $\begin{array}{c}677 . \\
9\end{array}$ & $\begin{array}{r}1.4 \\
5\end{array}$ & 1.5885 & $\begin{array}{c}313 . \\
0\end{array}$ & 691.3 & 681.7 & -9.6 \\
\hline
\end{tabular}




\section{Highlights}

- An equation to predict ORP in complex leaching solutions was extended

- $\mathrm{Fe}^{3+} / \mathrm{Fe}^{2+}$ concentrations can be determined based on measured ORP by this equation

- Traditional colorimetric or volumetric method for iron-determining can be replaced

- This equation was also supported by experimental results from literature 